\title{
Evangélicos no Brasil. Perfil socioeconômico, afinidades ideológicas e determinantes do comportamento eleitoral
}

\author{
Simone R. Bohn \\ Programa de Pós-Doutoramento em Ciência Política \\ da Universidade de São Paulo
}

\section{Resumo}

O artigo estuda as características socioeconômicas, opiniões e preferências dos evangélicos no Brasil. Os dados mostram uma forte tendência deste grupo a opiniões mais conservadoras, comparado a outros grupos religiosos. O artigo utiliza os dados do ESEB 2002.

Palavras-chave: Estudo Eleitoral Brasileiro; religião; comportamento eleitoral; evangélicos; cultura política

\section{Abstract}

The article analyses the socioeconomic aspects, opinions and political preferences of the evangelics in Brazil. The data show in this group a strong tendency to more conservative opinions, compared to other religions groups. The data come from the 2002 Brazilian Electoral Study.

Keywords: Brazilian Electoral Study; religion; electoral behavior; evangelics; political culture 
Dos cerca de 170 milhões de brasileiros, 26 milhões - ou seja, quinze por cento do total - se declararam, em 2000, como pertencendo à religião evangélica. 0 crescimento espantoso desse grupo e sua visibilidade na arena política nacional o tornaram objeto de diversos estudos. Em 1980, existiam 7.8 milhões de evangélicos no país. Esse grupo religioso também vem crescendo entre os legisladores e membros eleitos do Poder Executivo.

O objetivo desse trabalho é analisar três interpretações que emergem na literatura recente sobre o segmento evangélico. Em primeiro lugar, existe uma interpretação segundo a qual os evangélicos estariam associados a condições econômicas e sociais bastante adversas. A opção pelo evangelismo seria, portanto, característica de segmentos sociais desprovidos de recursos financeiros.

Enquanto essa primeira interpretação procura entender as razões subjacentes ao aumento do público evangélico, uma segunda busca captar seu padrão de comportamento político. Ela explicitamente vincula o público evangélico a posições usualmente associadas à direita do espectro político-ideológico. Em virtude de seu posicionamento moral e político, os evangélicos seriam, desse modo, parte da base social de uma "nova direita". Por fim, há o tópico dos determinantes do voto. A filiação evangélica, de acordo com alguns trabalhos, geraria lealdades políticas automáticas, no sentido do privilegiamento de candidaturas de nomes ligados ao evangelismo.

Nas próximas seções, além de tentar ratificar esses diagnósticos, mapearemos o comportamento político-eleitoral dos evangélicos no que se refere aos seguintes elementos: (1) seu nível de sofisticação política; (2) sua preferência partidária; e (3) os principais determinantes de seu comportamento eleitoral.

\section{O crescimento do público evangélico e seu comportamento eleitoral: algumas interpretações.}

Uma das principais novidades da arena religiosa no Brasil nas últimas décadas tem sido o crescimento das religiões evangélicas (Tabela 1). Se, em 1980, os evangélicos correspondiam a cerca de $6.6 \%$ da população brasileira, o último censo revelou que, em 2000, os adeptos dessas religiões perfazem aproximadamente $14,6 \%$ do total dos brasileiros (IBGE, 2000). 
Interpretações que enfatizam a existência de uma onda de ressacralização da existência - ou de "reencantamento do mundo" - são claramente insuficientes para apreender esse aumento da adesão à fé evangélica, uma vez que sua ocorrência é simultânea a um grande crescimento (absoluto e relativo) do número de brasileiros sem quaisquer vínculos religiosos ${ }^{1}$. Em 1980, esse último grupo se limitava a $1.6 \%$ da população - em 2000, chegou ao nível de $7.3 \%$ da população.

Alguns autores associam os dois fenômenos - o crescimento tanto da adesão ao evangelismo quanto do público irreligioso - ao deslocamento da centralidade da Igreja católica na conformação das relações entre Estado e religiões no Brasil2. De fato, apesar de os brasileiros ainda serem predominantemente católicos, a porcentagem dos membros pertencentes à Igreja Católica decresceu, em duas décadas, de $88.9 \%$ para $73.8 \%$. Enquanto que a população brasileira cresceu, entre 1980 e 2000, cerca de 42.3\%, o público católico cresceu apenas 18.1\%. Ou seja, a Igreja Católica vem perdendo espaço.

Essa interpretação que aponta o declínio da preeminência da Igreja Católica como fator importante no entendimento do aumento dos aderentes a outras religiões é insuficiente, no entanto, para a compreensão da perda de membros por parte das religiões afro-brasileiras (candomblé e umbanda) que, como confissões mediúnicas, teriam sido perseguidas nos períodos de hegemonia católica ${ }^{3}$.

\footnotetext{
1 Processo semelhante de aumento do público sem qualquer filiação religiosa também vem ocorrendo em alguns países da Europa. Knutsen (2004) mostra que, em média, esse segmento do eleitorado europeu - os países que ele examina são Alemanha, Bélgica, Dinamarca, França, Grã-Bretanha, Irlanda, Itália e Países Baixos - cresceu 10\% entre 1970 e 1997.

2 De acordo com Montero \& Almeida (2000), o processo de separação entre poder secular e poder temporal no Brasil, sagrado inicialmente pela Constituição de 1891, resultou na manutenção da centralidade da Igreja Católica. Ou seja, o processo de laicização da vida civil e política do país foi simultâneo à concessão, ao catolicismo, de uma preeminência sobre as demais religiões. Algumas delas, como as religiões mediúnicas, acabaram sendo perseguidas, não se beneficiando, durante longos períodos, da liberdade religiosa oficialmente existente. Essa posição de centralidade da Igreja Católica começou a se alterar nas últimas décadas, sobretudo no decorrer do regime militar quando ocorreu, segundo Montero \& Almeida (2000, p. 329), "o rompimento relativo de sua aliança com o Estado e as elites".

3 Como "as religiões mediúnicas foram recorrentemente perseguidas" - como mostram Montero \& Almeida (2000, p. 328), até o Código Penal de 1985 práticas associadas ao candomblé e à umbanda permaneciam sendo categorizadas como crimes contra a credulidade popular -, seria de se esperar que, ausentes as condições de restrição, elas florescessem.
} 
BOHN, Simone R. Evangélicos no Brasil...

\section{Tabela 1}

Distribuição da população brasileira segundo religiões (1980/2000)

\begin{tabular}{|l|c|c|c|}
\hline Religião & $\begin{array}{c}1980 \\
(\%)\end{array}$ & $\begin{array}{c}2000 \\
(\%)\end{array}$ & $\begin{array}{c}\text { Variação do N absoluto } \\
1980 / 2000(\%)\end{array}$ \\
\hline Católica & 88.9 & 73.8 & 18.1 \\
\hline Evangélica não-pentecostal & 3.4 & 4.2 & 78.0 \\
\hline Evangélica pentecostal & 3.2 & 10.4 & 357.9 \\
\hline Kardecistas & 0.7 & 1.4 & 171.9 \\
\hline Afro-brasileiras & 0.6 & 0.3 & -15.8 \\
\hline Outras & 1.2 & 1.6 & 79.7 \\
\hline Sem religião & 1.6 & 7.3 & 531.3 \\
\hline Sem declaração & 0.2 & 0.2 & 27.6 \\
\hline Total & 100 & 100 & -- \\
\hline População total do Brasil (N) & 119.011 .052 & 169.411 .759 & 42.3 \\
\hline
\end{tabular}

Fontes: IBGE (2000), IBGE (1982).

Quaisquer que sejam as razões da atração de membros das religiões católica e afro-brasileiras, o fato é que o crescimento do segmento evangélico não tem sido homogêneo. Entre 1980 e 2000, o crescimento desse grupo foi significativamente maior na região nordeste do que nas demais áreas do país sobretudo o sul ${ }^{4}$. Além disso, as religiões evangélicas pentecostais cresceram muito mais que as históricas ${ }^{5}$. De acordo com alguns autores, o avanço do evangelismo pentecostal ${ }^{6}$ pode ter sido facilitado pelo fato de o pentecostalismo não se tratar de uma religião inteiramente estrangeira, já que contém alguns elementos que são similares às práticas mediúnicas das religiões afro-brasileiras ${ }^{7}$.

\footnotetext{
${ }^{4}$ De acordo com o IBGE, na região nordeste do país, em 1980, os evangélicos correspondiam a 3.4\% da população. Em 2000, conformavam $10.3 \%$ dos habitantes da região. No sul, por sua vez, os evangélicos passaram de $9.8 \%$ (1980) para 15.3\% (2000). Nas demais regiões, os números são, respectivamente, os seguintes: norte, $7.9 \%$ e $19.7 \%$; sudeste, $7.2 \%$ e $17.5 \%$; e centro-oeste, $8.0 \%$ e $18.9 \%$.

5 As religiões evangélicas chamadas de não-pentecostais ou históricas compreendem, no Brasil, sobretudo as seguintes denominações: Igrejas Batista, Episcopal, Luterana, Metodista e Presbiteriana. Entre as evangélicas pentecostais principalmente: Assembléia de Deus, O Brasil para Cristo, Congregação Cristã no Brasil, Deus é Amor, Universal do Reino de Deus. A novidade incorporada pelas denominações pentecostais é a centralidade da crença na ação do Espírito Santo, manifesta através da reprodução, nos cultos, de partes do episódio de Pentecostes, em que o fiel supostamente fala em línguas estranhas.

${ }^{6}$ Para uma periodização do avanço do pentecostalismo no Brasil, ver, entre outros, Freston (1994).

7 Montero (1999, p. 358) salienta a importância do "modo pelo qual [o pentecostalismo] dialoga com a tradição religiosa africana, ao promover, em seus cultos, o exorcismo de Exus". Fernandes (1998), por sua vez, mostra que, no Grande Rio, cerca de $51 \%$ dos entrevistados evangélicos afirmaram ter recebido algum dom do Espírito Santo. Dentre eles, 22\% receberam o dom de falar em línguas estranhas e 3\%, de exorcizar demônios.
} 
Um outro padrão de explicação para o crescimento dos evangélicos volta-se para a deterioração do quadro socioeconômico do país. Segundo Fernandes et al (1998, p. 25), o "crescimento notável dos evangélicos decorre, sobretudo, de escolhas feitas pelos pobres". De acordo com outros autores, há uma forte associação não entre evangélicos em geral e agravamento da situação econômica, mas entre membros de igrejas pentecostais e condições indicativas de pobreza (PIERUCCI \& PRANDI, 1995; MONTERO \& ALMEIDA, 2000). Segundo Novaes (2001), os evangélicos pentecostais, além de possuir membros entre as camadas sociais menos privadas de recursos financeiros, conseguem penetrar nas franjas da sociedade: em áreas que têm se mostrado inalcançáveis para outros segmentos religiosos. São setores sociais (e espaços geográficos) que, por sua precariedade de condições, revelam, por outro lado, a mais completa ausência do poder público ${ }^{8}$.

O segmento evangélico é objeto de atenção acadêmica não só em virtude da sua expansão e da velocidade e natureza de seu crescimento e de sua eventual associação com a pobreza. A visibilidade dos evangélicos na arena eleitoral (sobretudo sua constante e cada vez maior presença na Câmara dos Deputados ${ }^{9}$ ), atrai olhares curiosos para quais seriam as bases de comportamento dos eleitores brasileiros pertencentes a essas denominações. Há uniformidades - no que se refere aos determinantes do voto, aos níveis de participação política, às atitudes cívicas, ao posicionamento ideológico - entre as diferentes denominações?

Diversos trabalhos demonstraram que a tese de que os evangélicos seriam totalmente apáticos em relação à esfera política não se sustenta (NOVAES, 1985; BURDICK, 1993; GOMES, 1996) ${ }^{10}$. Diante dessa constatação, vários mapeamentos do comportamento político dos evangélicos foram feitos. Baseado na atuação dos

\footnotetext{
8 Como lembra Montero (1999, p. 356), essa associação do pentecostalismo com condições sócio. econômicas adversas, em que a precariedade da presença estatal é patente, fez com que muitos autores equacionassem o crescimento das religiões evangélicas a "uma regressão da racionalidade e da modernização da vida pública - esse tipo de religião nasceria da pobreza e se alimentaria da falência da capacidade do Estado de responder às necessidades básicas da população". Burdick (1993), por outro lado, vê essa mesma associação sob prisma diferente. Seu trabalho descreve como as associações de bairro comandadas por evangélicos - ele analisa membros da Assembléia de Deus na região metropolitana do Rio de Janeiro - são geralmente mais eficazes na solução dos problemas locais em virtude da maior persistência e credibilidade de suas lideranças.

9 Sobre o crescimento da presença evangélica no cenário político nacional, ver, entre outros, Pierucci (1989), Freston (1993, 1994 e 2001), Fonseca (2002). Oro (2003), por sua vez, foca sua análise especificamente no êxito eleitoral da Igreja Universal do Reino de Deus e no seu impacto não só na arena política (em termos da busca, por parte dos políticos tradicionais, do apoio dos pastores evangélicos), mas também na arena religiosa (uma vez que outras denominações também passaram a lançar candidatos às eleições).

10 Esse apoliticismo dos evangélicos seria decorrente, em parte, da necessidade de manutenção da separação entre a esfera do sagrado e do profano e, em parte, da natureza da inserção do pentecostalismo no Brasil. Introduzido por missionários norte-americanos, o avanço do evangelismo pentecostal estaria associado ao não-engajamento na esfera política.
} 
deputados federais na Assembléia Nacional Constituinte, Pierucci (1989), por exemplo, apesar de reconhecer a existência do que ele denomina de uma "esquerda evangélica", afirma que os parlamentares membros das denominações pentecostais e não-pentecostais compõem uma espécie de "nova direita", na medida em que, além da defesa de bandeiras socioeconômicas direitistas tradicionais, eles se autoproclamam como os guardiões de uma moralidade familiar e social. Pierucci ressalta, no entanto, que, a despeito dessas similaridades, a bancada evangélica da legislatura não apresentou uma completa homogeneidade política e ideológica - um indicativo, segundo ele, da heterogeneidade das "bases de apoio" desse grupo ${ }^{11}$.

Pierucci \& Mariano (1992) mostram que o rechaço à candidatura esquerdista de Lula e a opção e trabalho pela candidatura de Fernando Collor, em 1989, decorreram do receio das lideranças evangélicas em relação a dois possíveis cenários: a implantação de um "comunismo ateu" numa eventual vitória de Lula, ou a retomada da preeminência da Igreja Católica, sobretudo dos setores ligados ao Partido dos Trabalhadores. Pierucci \& Prandi (1995), por sua vez, abandonam a perspectiva das lideranças e analisam o comportamento eleitoral dos evangélicos através de um survey. Assim como os demais trabalhos, no entanto, eles também acentuam os traços anti-esquerdistas de segmentos do campo evangélico ao detalhar que, pelo menos no que se refere à eleição presidencial de 1994, os pentecostais foram o grupo religioso que mais rejeitou a candidatura Lula.

Além do posicionamento do público evangélico à direita do espectro políticopartidário, há a questão dos determinantes do seu voto. Fonseca (2002, p. 237), afirma que os "eleitores evangélicos votam em seus pares, seus irmãos e pastores (...)"12. Fernandes et al (1998, p. 125), por sua vez, mostram que essa associação é especialmente intensa no que se refere aos pentecostais da Igreja Universal do Reino de Deus. Novaes (2001, p. 75), por outro lado, discorda da existência de lealdades religiosas automáticas a determinadas ofertas partidário-eleitorais, uma vez que, diante da enorme quantidade de igrejas evangélicas, "não há garantias de consensos entre denominações, nem de que evangélicos votem necessariamente de acordo com a orientação do pastor (...)".

De fato, as igrejas evangélicas são bastante diversas. Fernandes et al (1998) se depararam com 55 diferentes denominações. Na pesquisa ESEB 2002, cujos dados são utilizados aqui e detalhados adiante, exatas 68 denominações foram

\footnotetext{
${ }^{11}$ Alves (2000) mostra que, no município de São Paulo, o público que compõe a chamada "nova direita" é também pouco homogêneo.

12 Grifos do autor. Segundo Pierucci que escreve em 1989, "a partir deste final dos anos 80 o País pode contar com uma nova milícia de incentivadores da participação política das camadas mais pobres e marginalizadas da população. Nos dias que correm, o 'renascimento em Cristo', ou seja, a conversão ao evangelismo, mesmo o mais fundamentalista e menos politizado, pode representar para o converso uma inesperada via de acesso ao sistema de participação política. Porque, a partir de agora, 'irmão vota em irmão'.
} 
encontradas. Diante dessa variedade, é possível encontrar homogeneidade de comportamento político e eleitoral?

Uma consideração é fundamental antes de prosseguirmos em direção à exposição dos dados. O campo religioso evangélico está submetido a dois tipos de movimentos que atuam em direções contrárias. Um é caracteristicamente centrífugo, e o outro, centrípeto. Ambos, no entanto, têm impactos sobre as possibilidades de tradução da filiação religiosa em lealdade política. Por um lado, a ênfase evangélica na fidelidade ao local de culto evidentemente constitui-se num incentivo a um movimento de quase cissiparidade que afeta todas as denominações ${ }^{13}$. Essa ênfase no local de culto evidentemente inibe a formação de órgão(s) hierárquico(s) central(is) - de equivalentes ao papado católico em Roma que possa(m) induzir (ou agregar) e veicular preferências políticas homogêneas. Além disso, a intensa competitividade entre as diversas denominações também dificulta a constituição de pautas de ação política comuns ${ }^{14}$.

Por outro lado, por mais paradoxal que possa parecer diante do chamado "trânsito religioso" mencionado acima, as diferentes denominações evangélicas se homogeneizam em torno de uma exigência de dedicação exclusiva ao culto. Essa demanda tem implicações importantes, já que aumenta significativamente conforme veremos a seguir - os níveis de assiduidade dos seus membros aos cultos e, conseqüentemente, sua exposição à autoridade religiosa. Portanto, se, por um lado, há um mercado religioso competitivo, por outro, as autoridades das igrejas evangélicas são significativamente mais presentes na vida de seus membros. Ou seja, as lideranças evangélicas, em virtude da maior assiduidade dos fiéis, têm mais espaço para influenciá-los politicamente - se assim o desejarem. Esse ponto ficará mais claro adiante, quando examinarmos o nível de religiosidade do segmento evangélico - medido em termos de sua assiduidade ao culto - em comparação com as outras religiões.

\footnotetext{
${ }^{13}$ Como salienta Fernandes (1998, p. 41), a "Reforma Protestante promoveu uma radical dessacralização da hierarquia eclesiástica. As instituições eclesiais continuam a existir, naturalmente, mas o seu valor tende a ser reduzido a uma dimensão funcional. Por isto, não há dificuldades transcendentais em romper com uma igreja existente e fundar uma outra. A "Igreja", no sentido profundo, não está na hierarquia e em seus rituais. Ela tornase visível, apenas, no culto dos fiéis reunidos em assembléia."

14 Para uma descrição da magnitude das mudanças de filiação religiosa - de outras religiões para o interior do segmento evangélico e entre as diversas denominações - ver, entre outros, Prandi (1996), Pierucci \& Prandi (1995), Fernandes (1998) e Almeida \& Montero (2001).
} 


\section{Os dados do ESEB}

Realizada entre 31 de outubro e 28 de dezembro de 2002, o survey póseleitoral que compõe o Estudo Eleitoral Brasileiro (ESEB) utilizou-se de uma amostra probabilística sem substituição que abrangeu todas as regiões do país, num total de 2.513 entrevistas. No total, foram encontradas 88 diferentes religiões (contando individualmente cada uma das denominações evangélicas). Trabalharemos com duas sub-amostras, que categorizam os dados diferentemente. A primeira (Tabela 2) agrega todos os principais grupos religiosos e mantém os evangélicos não-pentecostais e pentecostais agregados num mesmo bloco ${ }^{15}$. 0 objetivo dessa agregação é caracterizar o público evangélico na comparação com os demais grupos religiosos, tentando captar eventuais diferenças entre os diversos segmentos.

Tabela 2

Distribuição das religiões brasileiras

(\% na população brasileira e \% na pesquisa ESEB)

\begin{tabular}{|l|c|c|}
\hline Religiões (\%) & IBGE 2000 & ESEB \\
\hline Católica & 73.8 & 69.2 \\
\hline Evangélica (total) & 15.4 & 15.8 \\
não-pentecostal & 4.2 & 3.7 \\
pentecostal & 10.4 & 11.1 \\
outros (sem especificação) & 0.8 & 1.0 \\
\hline Kardecistas & 1.4 & 2.5 \\
\hline Afro-brasileiras & 0.3 & 0.9 \\
\hline Outras & 1.6 & 4.0 \\
\hline Sem religião & 7.3 & 7.4 \\
\hline Sem declaração & 0.2 & 0.3 \\
\hline Total & 100 & 100 \\
\hline
\end{tabular}

Fontes: IBGE (2000); ESEB 2002

15 As religiões afro-brasileiras são candomblé e umbanda. Na categoria "outras", por sua vez, os principais grupos são os seguintes: religião judaica, budista, seisho-no-iê, messiânica, Perfeita Liberdade, Santo Daime. 
A segunda categorização enfoca especificamente o público evangélico e busca analisar as diferenças e homogeneidades inter-denominacionais. Por razões de densidade estatística trabalharemos com as seguintes denominações: Assembléia de Deus, Congregação Cristã no Brasil, Igreja Universal do Reino de Deus e Igreja Batista.

Tabela 3

Distribuição das principais denominações evangélicas no ESEB

\begin{tabular}{|l|c|c|}
\hline Religiões & $\%$ (Somente evangélicas) & $\%$ (Total da amostra) \\
\hline Assembléia de Deus & 30.8 & 5.1 \\
\hline Congregação Cristã no Brasil & 9.6 & 1.6 \\
\hline Igreja Universal do Reino de Deus pentecostais & 1.1 \\
\hline Outras pentecostais & 6.8 & 3.3 \\
\hline \multicolumn{2}{|c|}{ Evangélicas não-pentecostais } \\
\hline Batista & 12.9 & 2.1 \\
\hline Outras não-pentecostais & 9.8 & 1.6 \\
\hline \multicolumn{2}{|c|}{ Outras evangélicas } \\
\hline Não especificou denominação & 9.8 & 1.6 \\
\hline Total (Somente Evangélicas) & 100 & 16.5 \\
\hline Outras Religiões & & 100 \\
\hline Total geral & \\
\hline
\end{tabular}

Fonte: ESEB 2002

\section{O perfil socioeconômico}

O mapeamento do perfil socioeconômico dos diferentes grupos religiosos aqui realizado baseou-se nas duas variáveis clássicas a esse respeito: renda (mensal) e nível de escolaridade. A literatura corrente afirma haver, conforme já mencionamos, uma associação entre religião evangélica e precárias condições socioeconômicas. Deveríamos esperar, portanto, uma concentração de pessoas com baixa renda e baixo nível educacional entre os fiéis evangélicos. 
O Gráfico 1 contém as informações relativas à renda ${ }^{16}$. Há sete categorias de renda, desde no máximo um salário mínimo até mais de dez salários mínimos. De fato, como assinala a literatura, a maior parte dos membros das igrejas evangélicas advém de estratos sociais de baixa renda. Cerca de $67.7 \%$ dos evangélicos recebem mensalmente, no máximo, dois salários mínimos. Entre os dois segmentos sociais de maior renda (mais de seis salários mínimos), somente 8.9\% optaram por se filiar ao credo evangélico.

\section{Gráfico 1 - Distribuição das religiões segundo a renda mensal (em salários mínimos)}

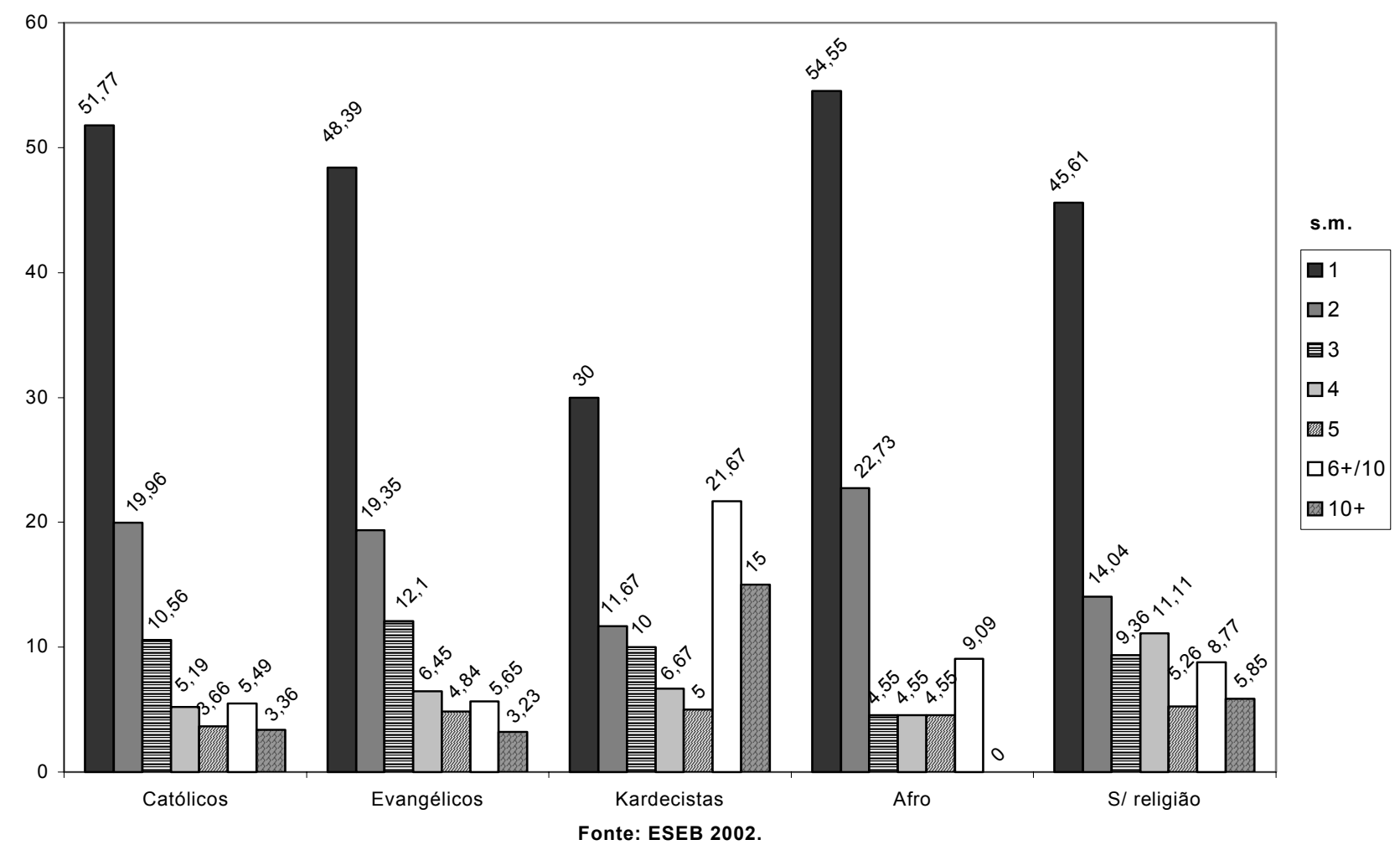

O interessante a observar no Gráfico 1, no entanto, é que esse perfil dos evangélicos guarda muitas similaridades em relação aos católicos e aos adeptos das religiões afro-brasileiras. Na verdade, encontram-se nesses dois últimos grupos as maiores concentrações (em termos relativos) de brasileiros com renda mensal de

16 Os dados mostrados no Gráfico 1 são estatisticamente significativos ao nível de 0.000 (valor de 75.2300) com base no teste do chi-quadrado. O valor de V de Cramér foi de 0.0912 . 
até dois salários mínimos: 77.3\% (candomblé e umbanda) e 71.7\% (católicos). Portanto, se há uma associação entre condições econômicas precárias e filiação à religião evangélica, essa associação - ao contrário do que parece sugerir a literatura - não é exclusiva a essa confissão.

Poderíamos pensar que essa similaridade decorre do fato de o pertencimento à uma religião ser, no Brasil, uma opção dos estratos sociais de baixa renda. No entanto, os dados mostram que $59.7 \%$ das pessoas sem vínculo religioso pertencem aos dois segmentos mais baixos de renda (Tabela 4). 0 perfil dos adeptos da religião kardecista valida esse mesmo ponto de uma maneira diferente. Entre eles, cerca de $36.7 \%$ dos praticantes advêm dos dois estratos sociais mais abastados da sociedade brasileira. Entre os sem religião, esse mesmo número corresponde a $14.6 \%$. Isso significa que a probabilidade de um indivíduo com renda elevada não ter religião é ligeiramente maior do que a probabilidade de ele ser católico, evangélico, candombleísta ou umbandista - mas é bem menor do que a probabilidade de ele ser praticante do kardecismo. É incorreto, portanto, afirmar categoricamente que a religiosidade, no Brasil, seja um fenômeno próprio aos segmentos menos privilegiados e que os grupos sociais mais abastados sejam maciçamente sem religião.

\section{Tabela 4}

Distribuição das religiões brasileiras por grupos de renda mensal (em salários mínimos)*

\begin{tabular}{|l|c|c|}
\hline Religião & Até 2 s.m. (\%) & Acima de 6 s.m. (\%) \\
\hline Católica & 71.7 & 8.9 \\
\hline Evangélica & 67.7 & 8.9 \\
\hline Kardecista & 41.7 & 36.7 \\
\hline Afro-brasileiras & 77.3 & 9.1 \\
\hline Sem religião & 59.7 & 14.6 \\
\hline
\end{tabular}

* Nível de significância de 0.000 no teste de qui-quadrado (valor de 75.2300)

Fonte: ESEB 2002 
Quando focamos apenas no segmento evangélico, vemos que há diferenças sensíveis em relação aos seus perfis socioeconômicos (Gráfico 2) ${ }^{17}$. Enquanto 70.3\% dos membros das denominações pentecostais recebem mensalmente, no máximo, dois salários mínimos, entre os fiéis das religiões não-pentecostais essa proporção é de 58.3\%. O contraste maior entre os dois grupos aparece na porcentagem de pessoas mais abastadas. Entre os pentecostais, essa proporção é de 6.8\%; já entre os não-pentecostais, chega a 16.7\%. Em ambos os grupos, há uma relação linear negativa entre renda e religião: quanto maior a renda mensal, menor a probabilidade de uma pessoa ser evangélica; no entanto, se um indivíduo com uma renda elevada optar pela confissão evangélica, a probabilidade de ele ser membro de uma religião não-pentecostal é maior do que ele ser um fiel das denominações pentecostais.

\section{Gráfico 2 - Distribuição de renda (em salários mínimos) entre evangélicos pentecostais e não-pentecostais}

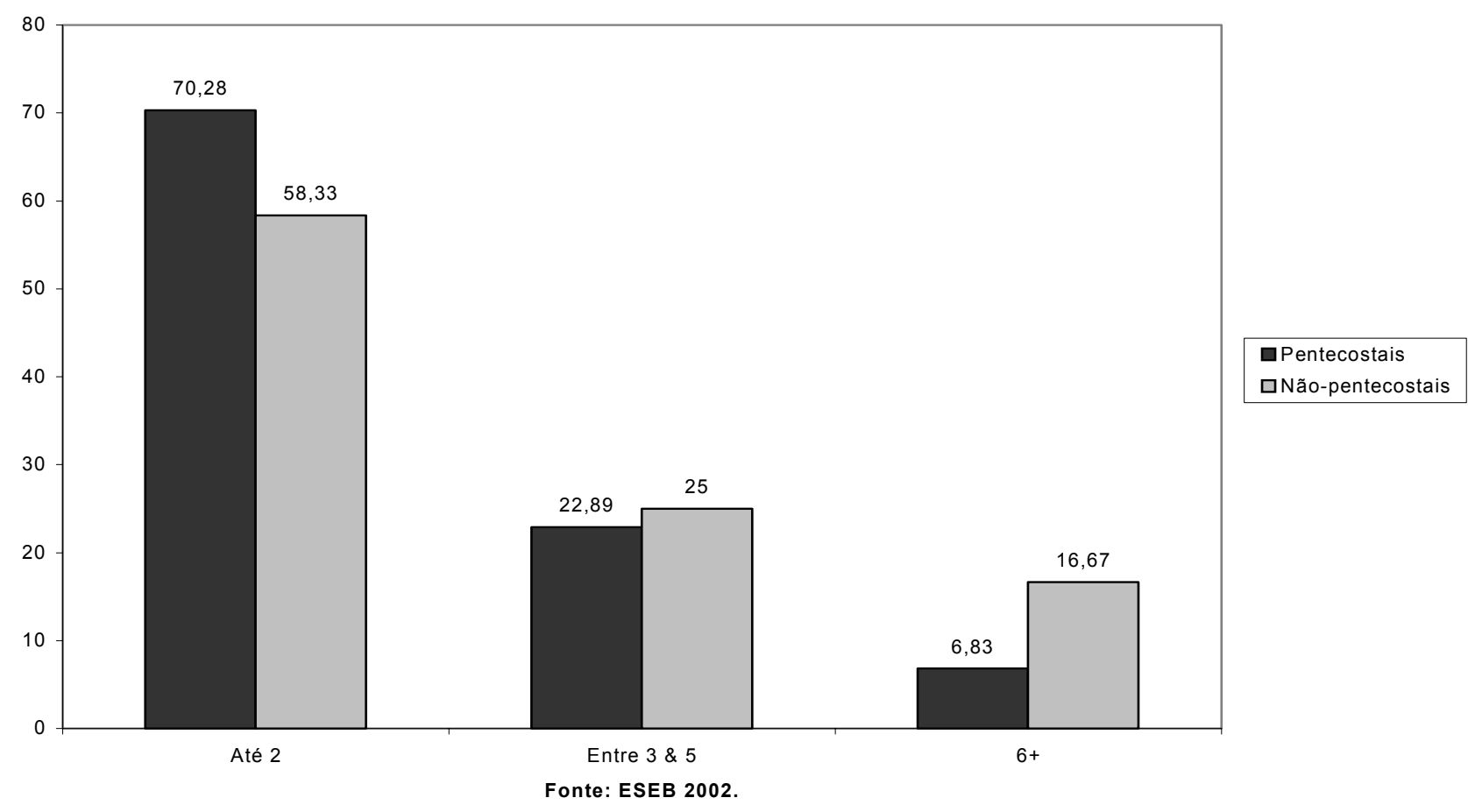

\footnotetext{
17 Estatisticamente significativo ao nível de 0.018 (valor de 7.9842) com base no teste do chi-quadrado.

O valor de $V$ de Cramér foi de 0.1548 .
} 
No que se refere aos níveis educacionais, católicos e evangélicos têm perfis bastante similares (Gráfico 3$)^{18}$. Enquanto entre os católicos $58.1 \%$ não concluíram o ensino fundamental, entre os evangélicos, esse número é $54.0 \%$. As pessoas com nível superior completo que se consideram fiéis da Igreja Católica correspondem a $6.3 \%$ do total dos adeptos dessa religião. Entre os evangélicos, essa proporção é de $5.6 \%$. O perfil de católicos e evangélicos contrasta fortemente com o dos kardecistas: entre esses últimos, $23.8 \%$ possuem nível universitário completo e apenas $27.0 \%$ não concluíram o ensino fundamental.

Apesar da similaridade com o perfil dos católicos e do contraste com os kardecistas, de fato, os dados revelam, consoante a literatura, uma relação linear negativa entre nível educacional e pertencimento à religião evangélica: quando maior a educação formal, mais baixos são os níveis de filiação a esse grupo religioso. Essa relação ou inexiste entre os outros grupos religiosos, ou é muito tênue. No entanto, que entre as pessoas com mais baixo nível educacional, a primeira preferência é ser católico - e não evangélico. Similarmente, o evangelismo não é a última escolha das pessoas com nível superior completo - e sim as religiões afro-brasileiras. Desse modo, se de fato há uma maior concentração de pessoas de baixo nível educacional entre os evangélicos (em comparação com outros graus de escolaridade), essa associação é bastante semelhante à existente entre os católicos.

\section{Gráfico 3 - D istribuição das religiões segundo o nível e d u c a c io n a I}

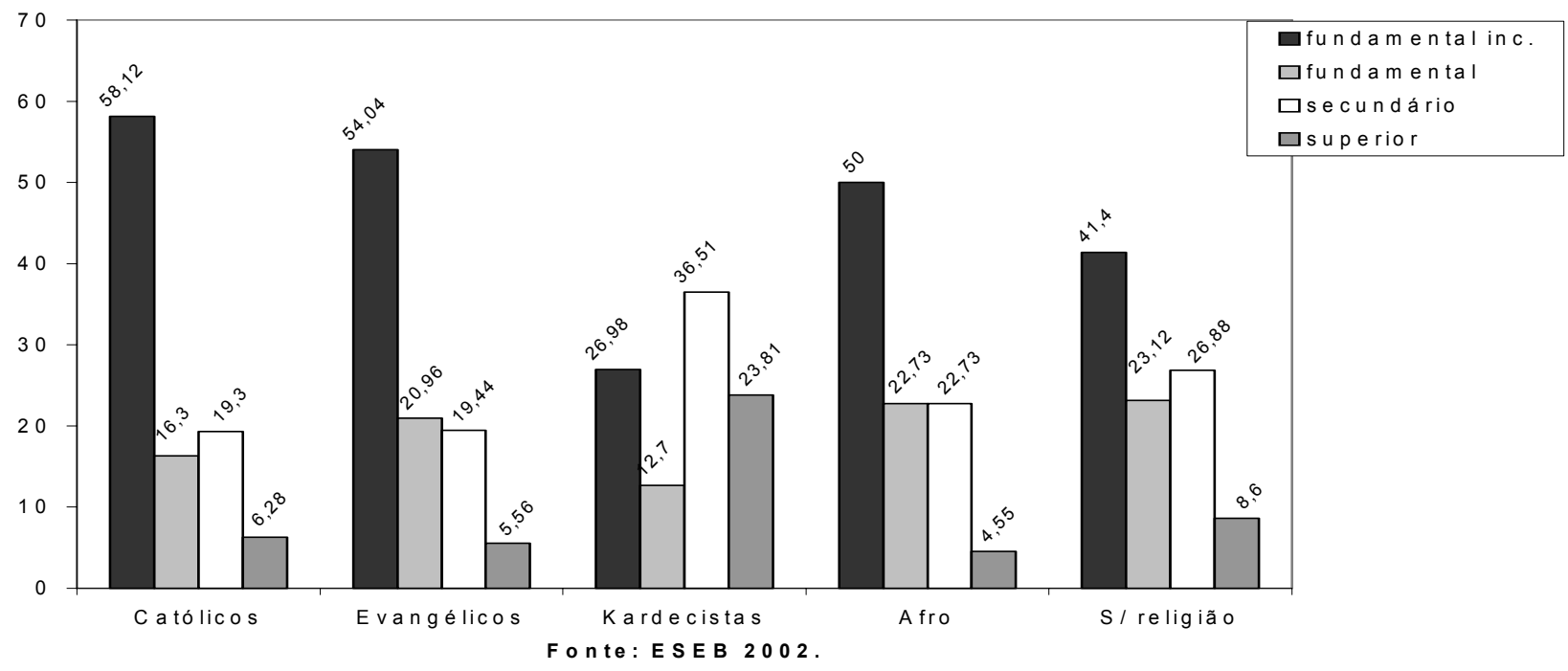

\footnotetext{
18 Estatisticamente significativo ao nível de 0.000 (valor de 69.6420) com base no teste do chi-quadrado. $\mathrm{O}$ valor de $\mathrm{V}$ de Cramér foi de 0.0983.
} 
Evangélicos pentecostais realmente possuem um menor nível de escolaridade que os evangélicos não-pentecostais (Tabela 5). Entre os que não concluíram o ensino fundamental, há quase o dobro de chance de uma pessoa ser adepta de uma religião pentecostal do que não-pentecostal. Cerca de $15.7 \%$ dos evangélicos não-pentecostais têm nível superior. Entre os membros das denominações não-pentecostais, essa proporção é de apenas $2.2 \%$.

\section{Tabela 5}

\section{Nível educacional no interior do segmento evangélico}

\begin{tabular}{|l|c|c|}
\hline Segmento & Pentecostal & Não-pentecostal \\
\hline Fundamental incompleto & 60.8 & 33.7 \\
\hline Fundamental & 21.6 & 17.1 \\
\hline Secundário & 15.3 & 44.6 \\
\hline Superior & 2.2 & 15.7 \\
\hline Total & 100 & 100 \\
\hline
\end{tabular}

* Nível de significância de 0.000 no teste de qui-quadrado (valor de 74.2239). V de Cramér: 0.2211.

Fonte: ESEB 2002

Com exceção da Igreja Universal do Reino de Deus, todas as denominações pentecostais têm perfil educacional bastante semelhante (Gráfico 4) (19 $^{19}$. Diferentemente dos fiéis da Assembléia de Deus e da Congregação Cristã no Brasil, mais da metade dos membros da Universal concluiu pelo menos o ensino fundamental. Além disso, cerca de $33.3 \%$ dos fiéis da Universal possuem o segundo grau completo - mais que o dobro das outras denominações. No caso de Assembléia de Deus e Congregação Cristã no Brasil, quanto maior o nível educacional, menor é a probabilidade de pertencimento à denominação.

\footnotetext{
19 Estatisticamente significativo ao nível de 0.000 (valor de 74.2239) com base no teste do chi-quadrado. O valor de $V$ de Cramér foi de 0.2211 .
} 


\section{Gráfico 4 - Distribuição dos evangélicos segundo o nível educacional}

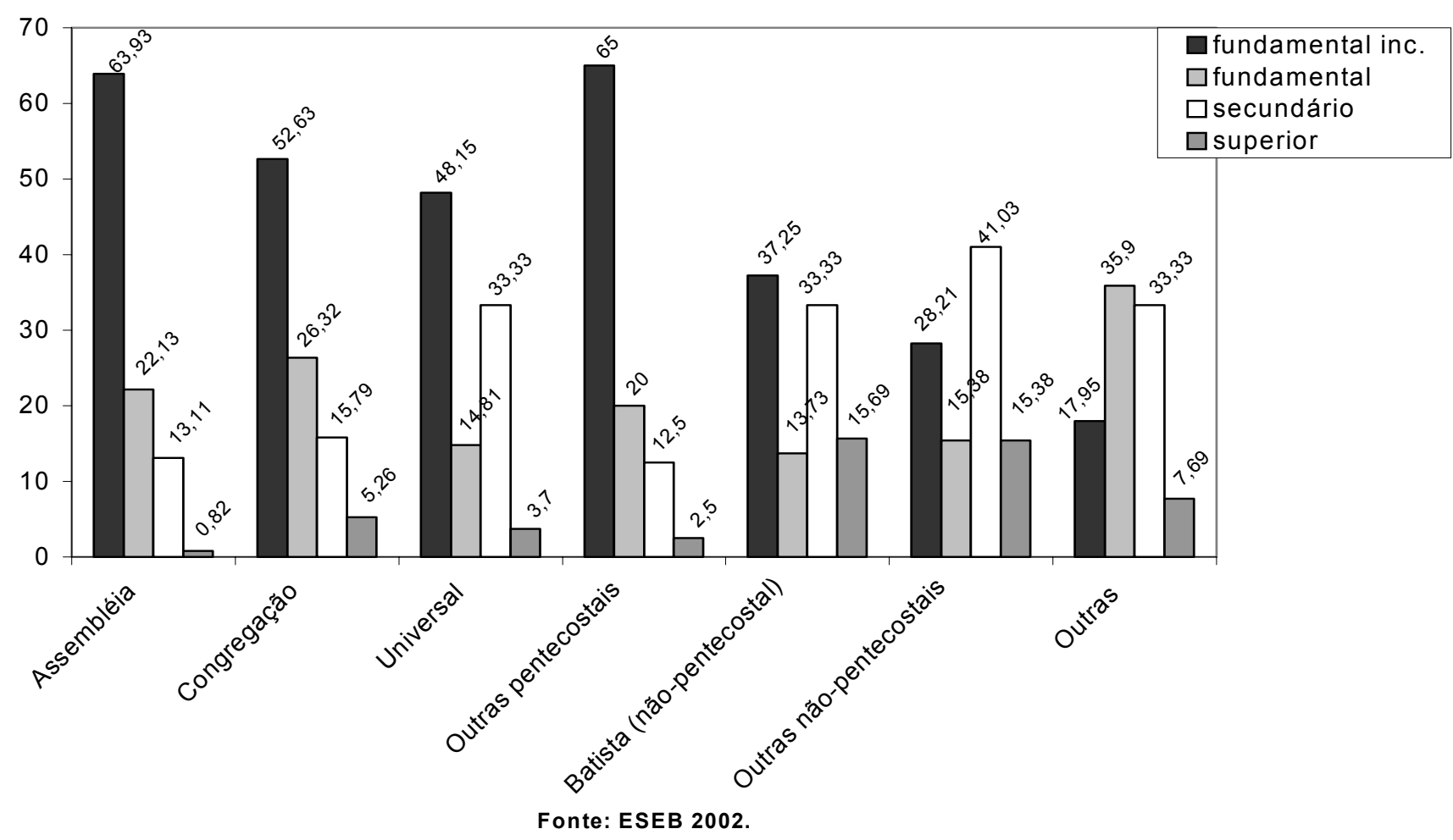

Do lado das religiões evangélicas não-pentecostais, entre os batistas, apenas $37.2 \%$ não completaram o ensino fundamental. Esse número é ainda menor no que se refere às demais denominações não-pentecostais: apenas 28.2\%. Há muitas similaridades entre batistas e membros da Igreja Universal do Reino de Deus no que se refere à proporção de indivíduos que concluiu os níveis fundamental e secundário: $13.7 \%$ e $33.3 \%$, no caso dos batistas; e $14.8 \%$ e $33.3 \%$, no caso da Universal, respectivamente.

O aporte de pessoas com nível universitário consiste num importante diferencial entre as denominações pentecostais e não-pentecostais. Entre os primeiros, a maior porcentagem de indivíduos com título universitário é de $5.3 \%$ entre os membros da Congregação Cristã no Brasil. Entre os batistas e outros fiéis não-pentecostais, esse nível é três vezes maior - supera os $15 \%$.

Se renda e educação não diferenciam claramente os evangélicos de outros grupos religiosos (como os católicos e membros do candomblé e umbanda), embora seja um importante divisor entre as denominações pentecostais e nãopentecostais, o grau de religiosidade é uma variável que distingue o evangelismo de 
maneira inequívoca. Por nível de religiosidade entendemos não a intensidade das crenças do fiel, mas seu grau de exposição às autoridades religiosas - medido pela freqüência com a qual ele participa de missas ou de cultos. Desse modo, um baixo grau de religiosidade indica que o fiel raramente vai a missas e cultos ou só participa deles algumas vezes por ano. Fiéis que possuem um nível médio de religiosidade vão à Igreja uma ou duas vezes por mês. Já o nível alto é composto por pessoas que vão à missa ou ao culto uma ou mais vezes por semana.

Como pode ser visto no Gráfico $5^{20}$, os evangélicos têm um alto grau de exposição às autoridades religiosas. Cerca de $82.6 \%$ deles vão ao culto uma ou mais vezes por semana. Os adeptos das religiões afro-brasileiras e do kardecismo são os que mais se aproximam do perfil evangélico: 50.0\% e 49.2\% deles, respectivamente, têm um alto grau de exposição às autoridades religiosas. Entre os católicos, esse número corresponde a apenas $35.7 \%$. Cerca de $41.6 \%$ dos católicos não vão ou raramente vão a missas. Já entre os evangélicos, essa porcentagem decresce para somente $9.9 \%$.

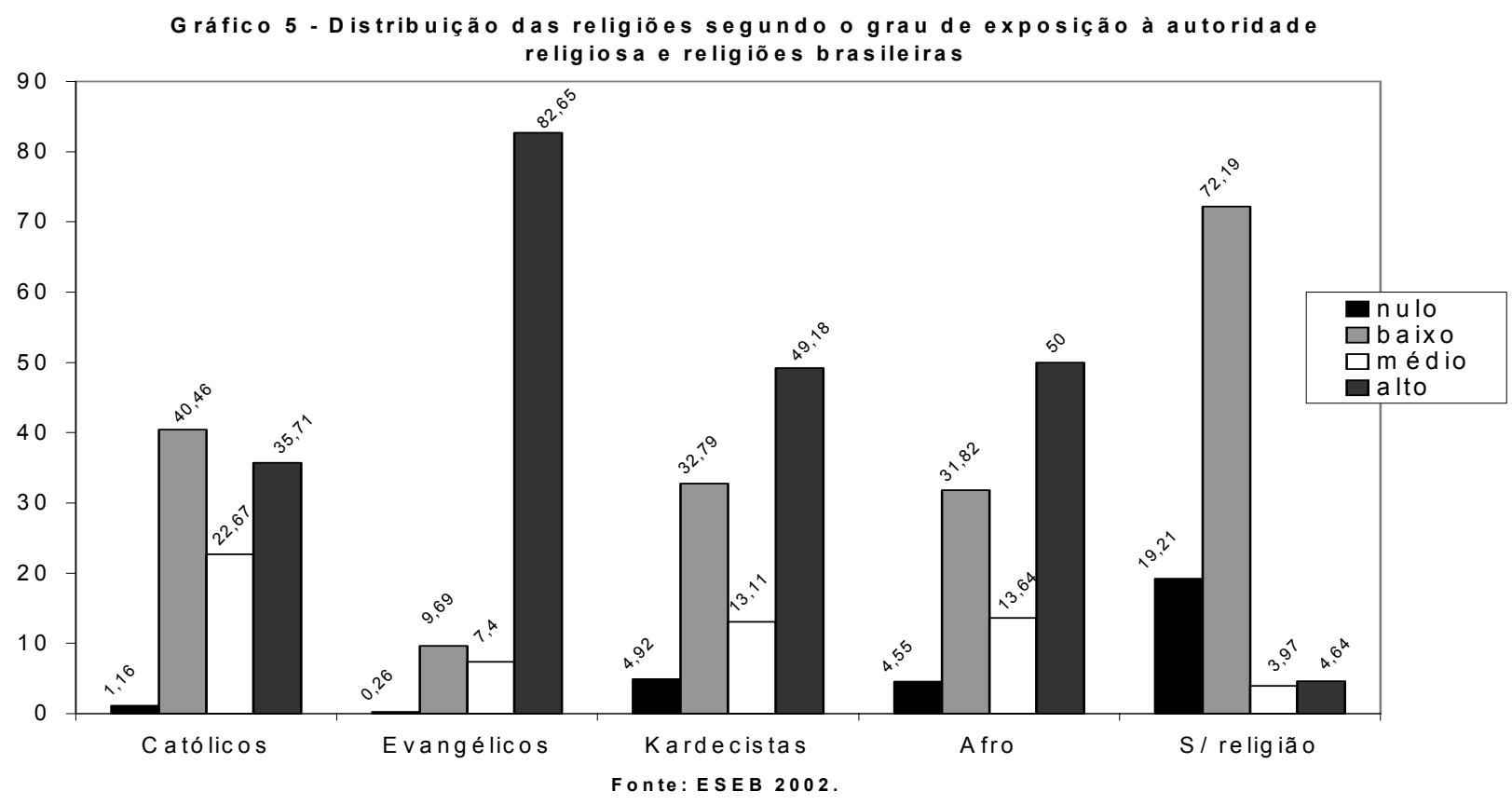

20 Estatisticamente significativo ao nível de 0.000 (valor de 624.4334) com base no teste do chiquadrado. O valor de $V$ de Cramér foi de 0.2975 . 
Esse elevado grau de exposição às autoridades religiosas é uma constante em todas as denominações evangélicas (Tabela 6). Mais uma vez, uma importante diferenciação aparece entre pentecostais e não-pentecostais: apesar de a porcentagem dos adeptos da religião batista que participa de cultos uma ou mais vezes (80.4\%) ser bastante semelhante à dos membros da Assembléia de Deus (80.3\%), cerca de $15.7 \%$ dos primeiros raramente vão ou só participam de cultos algumas vezes por ano. O mesmo se aplica aos membros de outras denominações não-pentecostais: entre eles, aproximadamente $17.9 \%$ têm um baixo grau de exposição às autoridades religiosas.

De todas as denominações examinadas, os fiéis da Igreja Universal do Reino de Deus são os mais assíduos: nove em cada dez freqüentam o culto uma ou mais vezes por semana. O caso dos membros da Universal chama a atenção, além disso, em virtude de outra razão. Quando todas as denominações evangélicas são analisadas em conjunto, os grupos com melhores níveis educacionais (batistas e outros grupos não-pentecostais) são simultaneamente os que possuem os menores graus de assiduidade. Quando nos restringimos somente ao segmento evangélico pentecostal, vemos que essa relação se inverte: os membros da Universal que compõem a denominação (entre os pentecostais) com grau considerável de educação formal, são os mais expostos às autoridades religiosas.

\section{Tabela 6}

Grau de exposição às autoridades religiosas *

\begin{tabular}{|l|c|c|c|}
\hline Denominação & Baixo & Médio & Alto \\
\hline Assembléia & 7.4 & 12.3 & 80.3 \\
\hline Congregação & 5.3 & 7.9 & 86.8 \\
\hline Universal & 3.8 & 3.8 & 92.3 \\
\hline Outras pentecostais & 5.1 & 5.1 & 89.7 \\
\hline Batista & 15.7 & 3.9 & 80.4 \\
\hline Outras não-pentecostais & 17.9 & 10.3 & 71.8 \\
\hline Não especificou denominação & 18.9 & 0 & 81.2 \\
\hline
\end{tabular}

* Nível de significância de 0.000 no teste de qui-quadrado (valor de 330.3842). $V$ de Cramér: 0.2164.

Fonte: ESEB 2002 
Essa variável - grau de exposição às autoridades religiosas -, medida pelo nível de assiduidade às missas ou cultos nos fornece duas considerações importantes. Por um lado, ela cria uma diferenciação entre católicos e evangélicos, cujos perfis são indistingüíveis quando somente renda mensal e nível de escolaridade são examinados. Portanto, caso existam diferenças entre esses dois grupos no que se refere ao padrão de comportamento político e eleitoral, elas não poderão ser atribuídas ao nível educacional, e vão estar mais conectadas com diferenças de socialização religiosa. Por outro lado, permite ainda diferenciações no interior do segmento evangélico, na medida em que o caso dos fiéis da Igreja Universal do Reino de Deus inverte a relação entre educação e assiduidade existente entre as denominações não-pentecostais.

Antes de examinarmos a orientação ideológica, analisemos o grau de sofisticação política dos diferentes grupos religiosos na seção seguinte.

\section{Sofisticação política}

Quanto maior a exposição de um indivíduo aos meios de comunicação de massa, maior tende a ser o seu grau de sofisticação política: ou seja, mais elevado tende a ser seu nível de conhecimento a respeito dos principais eventos, temáticas, símbolos e clivagens da esfera política.

De acordo com alguns autores, o papel dos meios de comunicação de massa em muito transcende essa função meramente informativa. Para Tocqueville (1977), muito mais do que informar sobre opções disponíveis, a principal virtude da liberdade de imprensa para os cidadãos numa democracia constitui-se no seu poder fiscalizatório: na capacidade que ela confere aos indivíduos não só de conhecer os eventos políticos, mas de poder utilizar esse conhecimento para eventualmente punir os governantes e a classe política ${ }^{21}$. Segundo Lipset (1967, p. 89), a imprensa tem um papel importante na socialização democrática dos indivíduos, na medida em que ao aumentar a exposição dos indivíduos às "pressões cruzadas" - à propaganda política de grupos de perfil programático ou ideológico bastante diferenciados - acentua as atitudes de tolerância à diversidade e diminui a probabilidade de aceitação de ideologias extremistas.

Neste trabalho, vamos nos ater ao papel meramente informativo da imprensa. Qual é o grau de exposição à imprensa dos diferentes grupos religiosos que compõem o eleitorado brasileiro? Eventuais diferenças no grau de exposição produzem níveis de sofisticação política diferenciados?

\footnotetext{
${ }^{21}$ Segundo Tocqueville (1977, p. 145), é o olho da imprensa, "sempre aberto, que constantemente põe a nu os redutos secretos da política e força os homens públicos a comparecer, cada um por sua vez, perante o tribunal da opinião."
} 
No que se refere aos jornais, os praticantes do kardecismo são os mais expostos (Gráfico 6) ${ }^{22}$. Cerca de $22.2 \%$ deles lêem jornais todos os dias e $52.4 \%$ deles os lêem uma ou algumas vezes por semana. Católicos e evangélicos têm perfis praticamente idênticos e são os únicos nos quais mais da metade do grupo não está exposta à imprensa escrita: $51.9 \%$ de cada segmento não possuem o hábito de ler jornal. A exposição desses grupos é consideravelmente limitada: apenas três em cada dez católicos ou evangélicos lêem jornais uma ou algumas vezes por semana. É desnecessário mencionar a associação entre a freqüência de leitura de jornal e grau de instrução ${ }^{23}$.

\section{Gráfico 6 - Distribuição das religiões segundo a freqüência de leitura de jornais e religiões brasileiras}

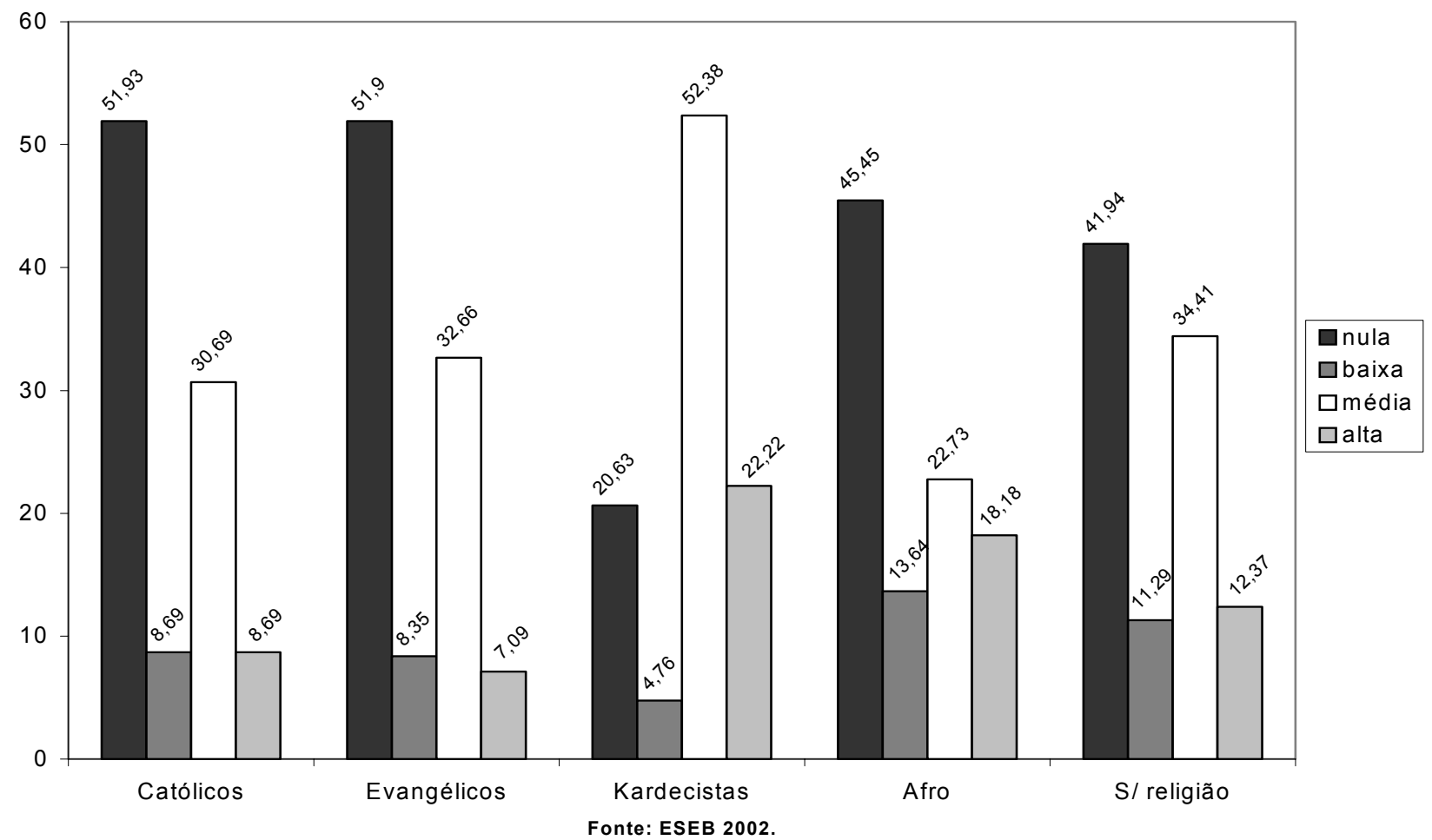

22 Os dados foram categorizados da seguinte maneira: alta freqüência agrupa o público que lê jornal todos os dias; freqüência média, o segmento que lê jornal uma ou algumas vezes por semana; baixa freqüência, os que raramente lêem e nula, os que não lêem. Os dados mostrados no Gráfico 6 são estatisticamente significativos ao nível de 0.000 (valor de 46.1982) com base no teste do chi-quadrado. $\mathrm{O}$ valor de $\mathrm{V}$ de Cramér foi de 0.0801 .

${ }^{23}$ Entre as pessoas mais escolarizadas, $87.7 \%$ lêem jornais pelo menos uma vez por semana. Entre o público menos escolarizado (que não completou o ensino fundamental), essa proporção é de $22.7 \%$. Esses dados são estatisticamente significativos ao nível de 0.000 (valor de 560.4074), com base no teste do chi-quadrado. O valor do V de Cramér foi de 0.2790 . 
O perfil de católicos e evangélicos também não se distingue no que se trata da exposição às notícias divulgadas em telejornais nacionais. Cerca de metade do público dessas duas religiões assistiu aos programas nacionais de notícias na semana da pesquisa. Esse percentual contrasta claramente com o perfil dos kardecistas - entre eles, apenas $19.3 \%$ não assistiram telejornais nacionais na semana da pesquisa.

Tabela 7

Público que assistiu telejornais nacionais na semana da pesquisa *

\begin{tabular}{|l|c|c|}
\hline Religião & Não $(\%)$ & Sim (\%) \\
\hline Católica & 50.1 & 49.9 \\
\hline Evangélica & 51.0 & 48.9 \\
\hline Kardecista & 19.3 & 80.6 \\
\hline Afro-brasileiras & 54.5 & 45.4 \\
\hline Sem religião & 43.8 & 56.2 \\
\hline
\end{tabular}

* Nível de significância de 0.000 no teste de qui-quadrado (valor de 25.5892). V de Cramér: 0.1034.

Fonte: ESEB 2002

É interessante observar que, entre os kardecistas, $79.4 \%$ estão de alguma maneira expostos à imprensa escrita e cerca de $80.6 \%$ assistem o noticiário nacional na televisão. Entre os católicos, 51.9\% não lêem jornais e $50.1 \%$ não estiveram expostos às notícias veiculadas nos telejornais nacionais na semana da pesquisa. Entre os evangélicos, esses mesmos indicadores também têm números bastante próximos entre si: 51.9\% e 51.0\%, respectivamente. O mesmo se aplica às pessoas sem filiação religiosa: $41.9 \%$ não lêem jornal e $43.8 \%$ não assistiram telejornais nacionais. Esses números implicam qualquer coincidência entre os dois públicos? Ou o segmento que acompanha a imprensa escrita é totalmente diferente do público exposto aos telejornais?

No interior do grupo evangélico, apenas $29.8 \%$ estão expostos a ambas as mídias (Tabela 8). Entre os católicos, esse número é levemente mais alto: 30.9\%. Cerca de $40.5 \%$ das pessoas sem religião estão expostas simultaneamente aos jornais e às notícias veiculadas na televisão. O dado mais importante a esse respeito é o fato de que cerca de $32 \%$ de evangélicos e de católicos não estão expostos a nenhum dos dois tipos de imprensa. Isso significa que suas opiniões, atitudes e concepções a respeito da esfera política são alimentadas e formuladas mediante o contato com outras fontes: seja a família, os amigos, colegas de trabalho, vizinhos, autoridades religiosas. 
OPINIÃO PÚBLICA, Campinas, Vol. X, no 2, Outubro, 2004, p. 288-338

Tabela 8

Exposição aos jornais e aos telejornais (em \%)

\begin{tabular}{|l|c|c|c|c|c|l|l|l|}
\hline \multicolumn{9}{|c|}{ Católicos } \\
\hline Evangélicos & Não & Sim & Telejornais & Não & Sim & Telejornais & Não & Sim \\
\hline Telejornais & 32.6 & 19.2 & Não & 32.9 & 18.9 & Não & 26.5 & 15.7 \\
\hline Não & 18.4 & 29.8 & Sim & 17.2 & 30.9 & Sim & 17.3 & 40.5 \\
\hline Sim & \multicolumn{2}{|c|}{$(396)$} & Total (N) & \multicolumn{2}{c|}{$(1725)$} & Total (N) & $(185)$ \\
\hline Total (N) & $\begin{array}{c}0.000(24.1528) \\
0.2470\end{array}$ & \multicolumn{3}{|c|}{$0.000(132.0168)$} & \multicolumn{2}{c|}{$0.000(19.8560)$} \\
\hline $\begin{array}{l}\text { Chi-quadrado } \\
\text { (valor) } \\
\text { V de Cramér }\end{array}$ & \multicolumn{2}{|c|}{0.2766} & \multicolumn{2}{c|}{0.3276} \\
\hline
\end{tabular}

Fonte: ESEB 2002

Como esses graus de exposição aos meios de comunicação de massa moldam a cognição de cada um desses grupos religiosos? Selecionamos duas temáticas relacionadas à política partidária e verificamos o grau de conhecimento dos diferentes públicos religiosos a respeito delas. A primeira temática solicita aos entrevistados que respondam qual partido político tem o número 13 como símbolo de sua legenda. A segunda indaga acerca de qual é o partido do ex-Presidente Fernando Henrique Cardoso.

Em relação ao grau de conhecimento do partido político cujo número na justiça eleitoral é 13 - o Partido dos Trabalhadores -, os kardecistas conformam o grupo com a maior proporção de acertos (80.9\%), seguidos do grupo sem religião (80.6\%) e dos adeptos das religiões afro-brasileiras (72.7\%) (Gráfico $7^{24}$ ). 0 perfil de evangélicos e católicos a esse respeito é praticamente idêntico. A porcentagem de acerto entre os evangélicos (66.4\%), no entanto, é ligeiramente menor do que a dos católicos (66.9\%). Entre os evangélicos também se encontra a maior proporção dos que não souberam ou não lembraram a resposta correta.

\footnotetext{
${ }^{24}$ Estatisticamente significativo ao nível de 0.005 (valor de 21.8367) com base no teste do chi-quadrado. $\mathrm{O}$ valor de $\mathrm{V}$ de Cramér foi de 0.0675 .
} 


\section{Gráfico 7 - Distribuição das religiões segundo o conhecimento do partido político cujo número é 13}

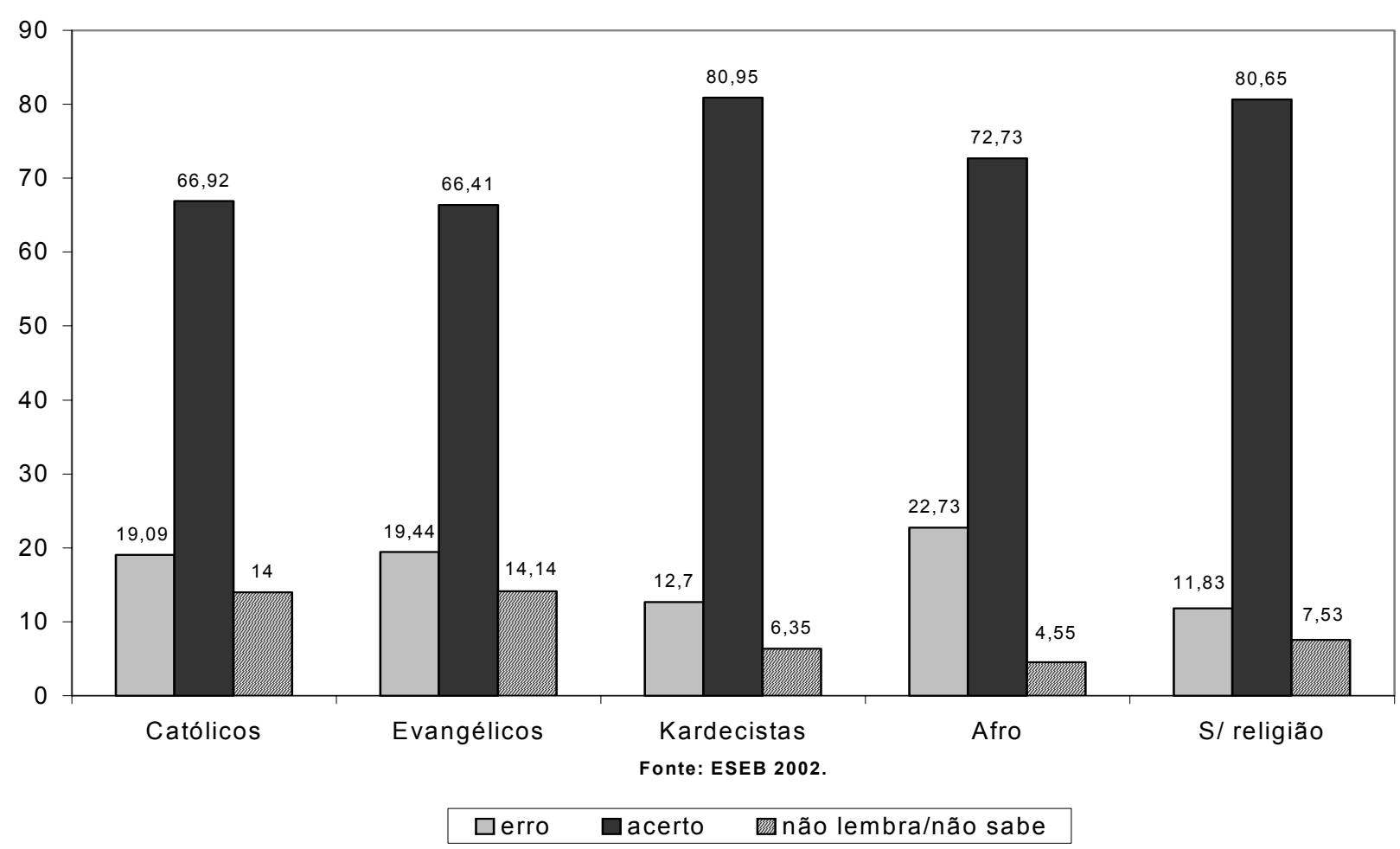

A indagação a respeito do partido do ex-Presidente Cardoso apresentou um nível maior de dificuldade para todos os segmentos (Gráfico $8^{25}$ ). Cerca de $47.6 \%$ dos kardecistas responderam corretamente essa pergunta - em contraste com os 80.9\% que deram uma resposta correta para a questão anterior. Entre todos os grupos, encontra-se entre os evangélicos a maior porcentagem dos que não sabiam ou não se lembraram que o PSDB era a resposta correta. Os evangélicos, além disso, obtiveram a segunda pior proporção de acerto - só superior a dos adeptos do candomblé e umbanda.

Uma vez mais, o perfil de evangélicos e católicos guarda significativas semelhanças. A porcentagem de acerto entre os católicos foi de $35.3 \%$; entre os evangélicos, $34.6 \%$. Os segundos erraram menos que os primeiros. A proporção dos que não souberam ou não se lembraram entre os católicos, no entanto, é ligeiramente inferior (41.9\%) do que a dos evangélicos (46.2\%).

\footnotetext{
${ }^{25}$ Estatisticamente significativo ao nível de 0.006 (valor de 21.5427) com base no teste do chi-quadrado. $\mathrm{O}$ valor de $\mathrm{V}$ de Cramér foi de 0.0670 .
} 


\section{Gráfico 8 - Distribuição das religiões segundo o conhecimento do partido do ex-Presidente Fernando Henrique Cardoso}

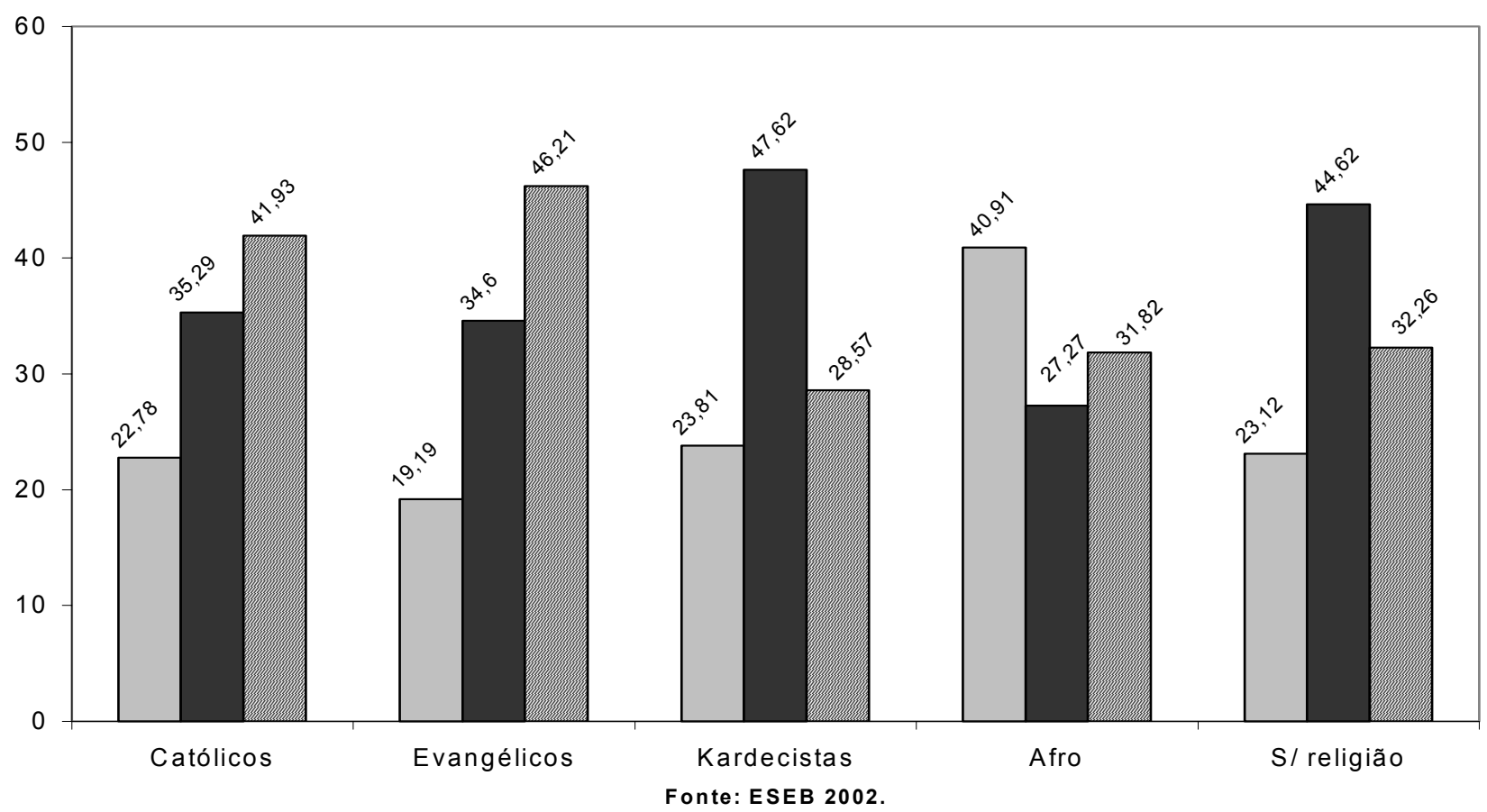

$\square$ erro $\square$ acerto 圈 não lembra/não sabe

No interior do segmento evangélico, os membros das igrejas nãopentecostais têm um desempenho superior aos das pentecostais (Tabela 9). Enquanto entre os primeiros, a porcentagem média de acerto foi de $50.7 \%$, entre os evangélicos pentecostais foi de apenas $28.5 \%$. Os membros da Congregação Cristã no Brasil - que, entre os pentecostais, têm nos seus quadros a maior proporção de pessoas com nível superior completo - foram os que mais acertaram (31.6\%). A maioria dos fiéis das denominações pentecostais examinadas simplesmente ou desconhecia ou não recordou a resposta correta. 
BOHN, Simone R. Evangélicos no Brasil...

Tabela 9

Qual é o partido do ex-Presidente Fernando Henrique Cardoso?*

\begin{tabular}{|l|c|c|c|}
\hline Denominação & Erro (\%) & Acerto (\%) & Não sabe / não lembra (\%) \\
\hline Assembléia & 21.3 & 25.4 & 53.3 \\
\hline Congregação & 15.8 & 31.6 & 52.6 \\
\hline Universal & 18.5 & 25.9 & 55.6 \\
\hline Outras pentecostais & 25.0 & 31.2 & 43.7 \\
\hline Batista & 19.6 & 45.1 & 35.3 \\
\hline Outras não-pentecostais & 2.6 & 56.4 & 41.0 \\
\hline Não especificou denominação & 20.5 & 43.6 & 35.9 \\
\hline
\end{tabular}

* Nível de significância de 0.020 no teste de qui-quadrado (valor de 24.1219). V de Cramér: 0.1745.

Fonte: ESEB 2002

A exposição a pelo menos um dos meios de comunicação de massa aumenta significativamente o nível de sofisticação política, conforme pode ser observado na Tabela 10. Na primeira questão, a porcentagem média de acerto (computando evangélicos e católicos conjuntamente) é $31.8 \%$ maior entre os que tiveram contato com a imprensa escrita ou televisada do que os que não tiveram nenhuma exposição. No caso da segunda questão que, como vimos anteriormente, introduziu um nível maior de dificuldade, a exposição à imprensa aumenta em cerca de $96.6 \%$ a porcentagem de respostas corretas. É interessante notar ainda que, em todos os segmentos, a leitura de jornais traz mais ganhos de acuidade do que o acompanhamento de notícias pelos telejornais nacionais.

\section{Tabela 10}

Porcentagem de respostas corretas (controladas por exposição à imprensa)

\begin{tabular}{|c|c|c|c|c|}
\hline Religião & Evar & licos & \multicolumn{2}{|c|}{ Católicos } \\
\hline \multicolumn{5}{|c|}{ Partido cujo número é 13} \\
\hline$\%$ & Jornais & telejornais & Jornais & Telejornais \\
\hline Não & 56.6 & 58.9 & 55.7 & 60.1 \\
\hline Sim & 77.0 & 74.2 & 79.0 & 74.1 \\
\hline & $\begin{array}{c}0.000(22.1803) \\
0.2367\end{array}$ & $\begin{array}{c}0.005(10.4074) \\
0.1621\end{array}$ & $\begin{array}{c}0.000(121.0024) \\
0.2648\end{array}$ & $\begin{array}{c}0.000(39.0761) \\
0.1508\end{array}$ \\
\hline \multicolumn{5}{|c|}{ Partido do ex-Presidente Cardoso } \\
\hline$\%$ & Jornais & telejornais & Jornais & Telejornais \\
\hline Não & 23.9 & 23.8 & 23.2 & 24.2 \\
\hline Sim & 46.1 & 45.9 & 48.4 & 46.5 \\
\hline & $\begin{array}{c}0.000(33.6536) \\
0.2915\end{array}$ & $\begin{array}{c}0.000(25.2390) \\
0.2525\end{array}$ & $\begin{array}{c}0.000(154.8145) \\
0.2991\end{array}$ & $\begin{array}{c}0.000(120.6412) \\
0.2646\end{array}$ \\
\hline
\end{tabular}

Fonte: ESEB 2002 
Evangélicos novamente têm uma performance semelhante à dos católicos. Essa similaridade se deve à ação de fatores mencionados anteriormente - renda e educação. Conforme vimos na terceira seção, essas variáveis não distinguem claramente os evangélicos dos demais grupos. Pelo contrário, mostramos como seu perfil - no que se refere a esses dois quesitos - é praticamente idêntico ao dos católicos. $O$ nível de exposição às autoridades religiosas (medido pela assiduidade do fiel ao seu culto), no entanto, constitui-se numa característica que singulariza o segmento evangélico. Mostramos como cerca de $82.6 \%$ dos membros das diversas denominações evangélicas participam de seus cultos uma ou mais vezes por semana.

Salientamos anteriormente que a exposição à imprensa aumenta significativamente os níveis de sofisticação política. Pontuamos, entretanto, que cerca de $32 \%$ dos evangélicos não estão expostos nem aos jornais e nem aos telejornais nacionais. Isso significa que há, entre os evangélicos, devido à combinação de alta exposição às autoridades religiosas e baixa exposição aos veículos da imprensa, um espaço importante para que os inputs eventualmente recebidos na esfera religiosa sejam transformados em guias para formação de opiniões e crenças e para o comportamento eleitoral e político concreto.

Antes de examinarmos a eventual influência que as autoridades religiosas possam ter no comportamento político e eleitoral dos evangélicos, vamos tentar mapear seu posicionamento do espectro ideológico brasileiro.

\section{Valores e opiniões}

$\mathrm{O}$ tradicionalismo pode ou não se traduzir em conservadorismo político. Ou seja, posturas tradicionalistas atinentes à moral social - como, por exemplo, a oposição ao aborto e ao homossexualismo - nem sempre são acompanhadas por posições políticas conservadoras. A relação inversa também procede: nem sempre o alinhamento em torno de uma plataforma conservadora no plano político está associado à defesa de bandeiras tradicionalistas a respeito do código moral que deve guiar os indivíduos em sociedade ${ }^{26}$.

De acordo com Pierucci (1989), a novidade representada pelo segmento evangélico seria a junção de ambas as dimensões. As denominações evangélicas, segundo esse autor, formam parte da base social da "nova direita", já que adicionam valores tradicionalistas referentes à família e à sexualidade aos pilares usualmente associados a posições direitistas, tais como a defesa do direito de

\footnotetext{
${ }^{26}$ Mannheim (1972) trabalha as diferenças entre tradicionalismo e conservadorismo.
} 
BOHN, Simone R. Evangélicos no Brasil...

propriedade, a resistência em relação à reforma agrária e à ampliação da intervenção do estado na economia.

O propósito dessa seção é ratificar a pertinência desse diagnóstico. Com esse objetivo, analisamos o posicionamento dos evangélicos em comparação com os outros grupos religiosos, no que se refere a tópicos relativos à moralidade social, como o aborto e o homossexualismo. Em seguida, apresentamos sua posição face a uma forma coletiva de protesto: as greves contra o governo. Ao final da seção, descrevemos seu posicionamento no que tange à participação do Estado na economia.

A temática do aborto revela dados interessantes muito mais a respeito da sociedade brasileira em geral do que sobre os evangélicos especificamente (Gráfico 9) ${ }^{27}$. A maior porcentagem de pessoas que aprovam a realização de práticas abortivas em qualquer situação encontra-se entre os indivíduos sem vínculos religiosos e é de apenas $16.9 \%$. Isso significa, portanto, que, em todos os grupos aqui listados, mais de $80 \%$ se revelam favoráveis ou à proibição total ou parcial do aborto. Os evangélicos são os mais tradicionalistas a esse respeito: entre eles encontra-se a maior proporção de pessoas contrárias ao aborto em qualquer situação (46.7\%). Entre os demais grupos religiosos, a maioria defende a limitação do aborto aos casos de gravidez indesejada decorrentes de violência sexual. Entre os católicos, essa maioria é de $49.3 \%$; kardecistas, $62.7 \%$; e adeptos do candomblé e umbanda $68.2 \%$. Portanto, os evangélicos, de fato, são os mais tradicionalistas no que diz respeito a esse tema, mas é fundamental perceber, no entanto, que a postura anti-aborto é comum a todos os segmentos religiosos.

27 Os dados mostrados no Gráfico 9 são estatisticamente significativos ao nível de 0.000 (valor de 52.8614) com base no teste do chi-quadrado. O valor de V de Cramér foi de 0.2108. 


\section{Gráfico 9 - Distribuição das religiões segundo a posição em relação ao aborto}

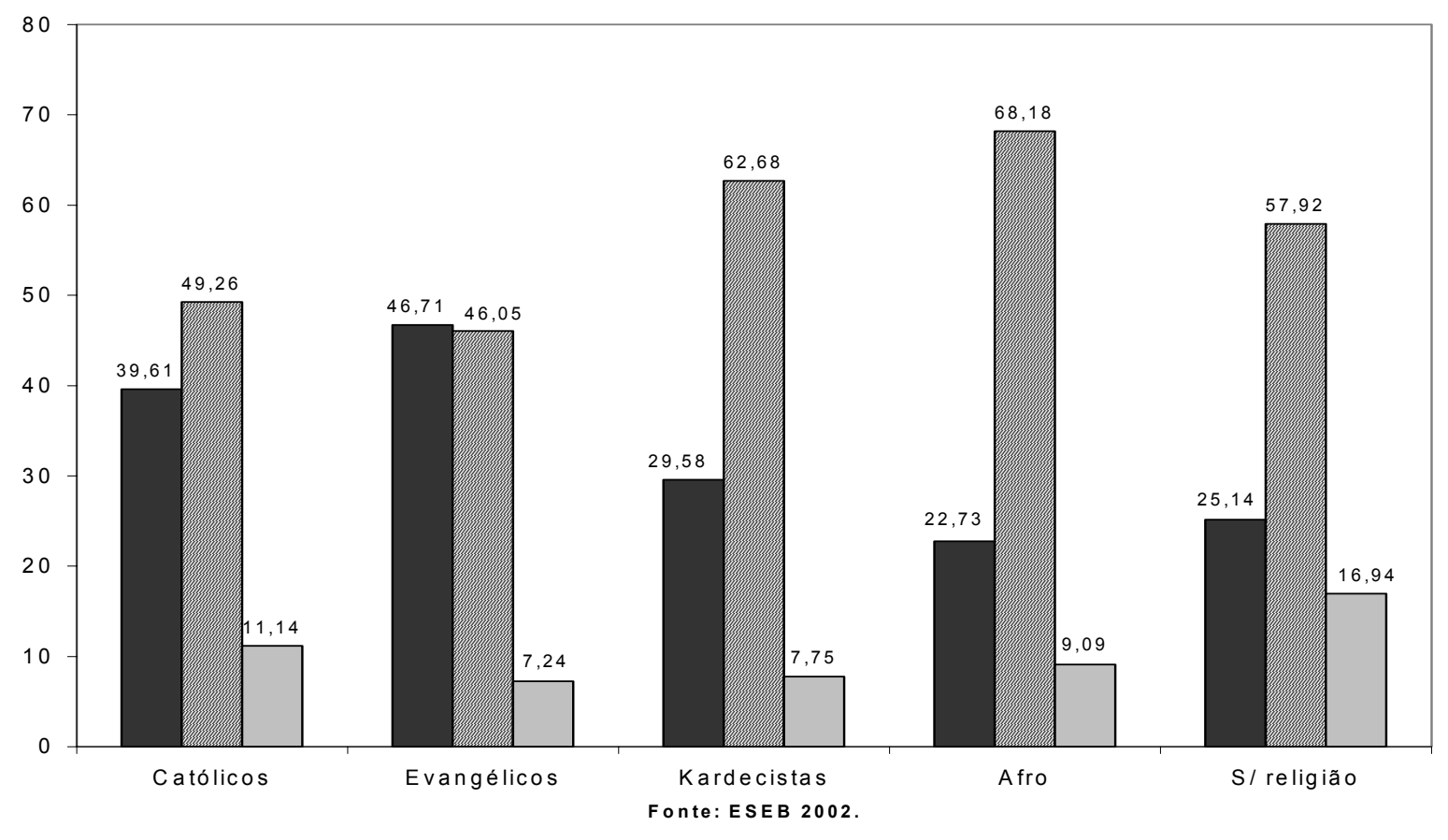

Perguntados sobre sua visão acerca do homossexualismo masculino, os entrevistados tiveram que escolher três tipos de respostas: a) as pessoas são livres para determinar seu comportamento sexual; b) o homossexualismo é uma escolha de indivíduos que desrespeitam a moral social ("são pessoas sem vergonha"), ou c) os homossexuais são pessoas doentes. Como pode ser visto no Gráfico $10^{28}$, esse é um tópico que claramente distingue os evangélicos dos demais grupos religiosos. Os membros das religiões evangélicas têm uma atitude francamente negativa: cerca de 84.3\% consideram o homossexualismo imoral ou doentio. Enquanto, entre os evangélicos, $15.7 \%$ consideram que as pessoas são livres para realizar suas escolhas sexuais, esse percentual praticamente dobra entre os católicos (31.0\%). As pessoas sem vínculos religiosos formam o grupo menos negativo a respeito do tema: $59.3 \%$ deles crêem que a opção sexual é livre e não associam o homossexualismo à imoralidade ou a qualquer doença.

\footnotetext{
28 No teste de chi-quadrado, as duas últimas opções - a associação do homossexualismo à imoralidade e à doença - foram agrupadas. Os dados mostrados no Gráfico 10 são estatisticamente significativos ao nível de 0.000 (valor de 29.9559). O valor de V de Cramér foi de 0.1587.
} 
Gráfico 10 - Distribuição das religiões segundo a posição em relação ao homossexualismo masculino

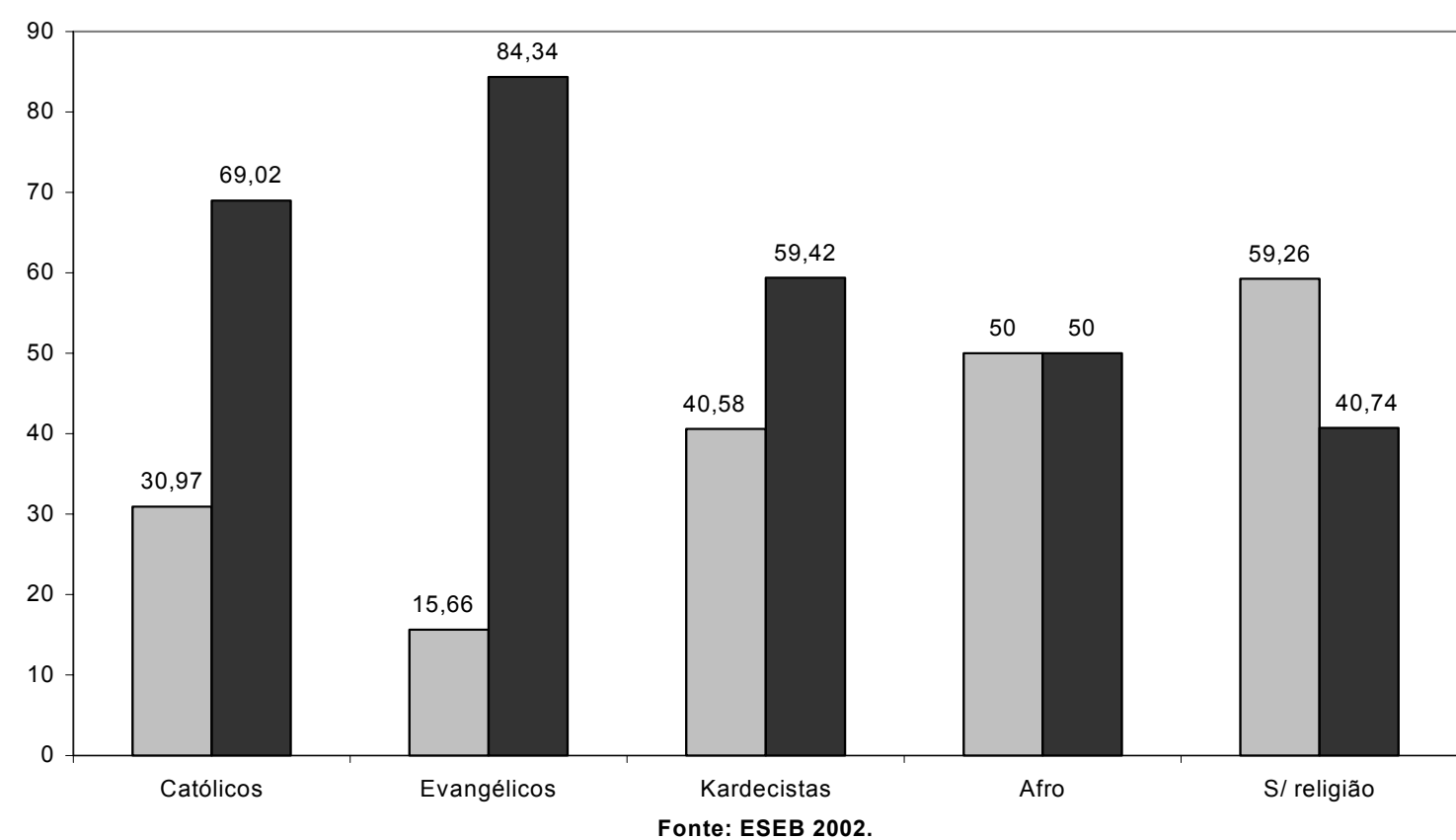

Internamente ao grupo, evangélicos pentecostais e não-pentecostais são indistingüíveis no que se refere à questão homossexual (Tabela 11). Todos, em sua maioria, reagem negativamente: mais de $74 \%$ deles consideram o homossexualismo uma imoralidade ou uma doença, a única exceção são os membros da Igreja Universal do Reino de Deus: cerca de $45.4 \%$ dos seus fiéis consideram que a liberdade individual rege a escolha e o comportamento sexuais.

Tabela 11

Distribuição dos evangélicos segundo a posição sobre o homossexualismo masculino*

\begin{tabular}{|l|c|c|}
\hline Denominação & Escolha sexual é livre (\%) & Imoralidade ou doença (\%) \\
\hline Assembléia & 10.3 & 89.7 \\
\hline Congregação & 23.8 & 76.2 \\
\hline Universal & 45.4 & 54.5 \\
\hline Outras pentecostais & 12.5 & 87.5 \\
\hline Batista & 21.0 & 78.9 \\
\hline Outras não-pentecostais & 26.3 & 73.7 \\
\hline Não especificou denominação & 16.7 & 83.3 \\
\hline
\end{tabular}

*Nível de significância de 0.000 no teste de qui-quadrado (valor de 29.9559); V de Cramér: 0.1587. Fonte: ESEB 2002 
Essas mesmas tendências repetem-se quando o tema da escolha sexual é abordado com enfoque na regulação do espaço público. Os entrevistados manifestaram-se contra ou a favor a veiculação hipotética de um programa de televisão que defendesse o casamento entre pessoas do mesmo sexo.

Consoante com sua visão marcadamente negativa a respeito do homossexualismo, os evangélicos se mostraram, em sua maioria (79.1\%), favoráveis à proibição do referido programa (Gráfico 11$)^{29}$. Entre os católicos essa proporção foi de $63.4 \%$. Mais uma vez não há diferenças significativas entre pentecostais e não-pentecostais ${ }^{30}$. Em relação aos demais grupos religiosos, surgem alguns pontos interessantes. Segmentos que não têm, em sua maioria, uma visão negativa da homossexualidade, acham, no entanto, que sua divulgação ou debate na televisão devem ser contidos. Assim, apesar de cerca de $59 \%$ das pessoas sem vínculos religiosos considerarem a escolha sexual como objeto da liberdade individual, $52.2 \%$ delas mostraram-se dispostos a proibir a veiculação do programa. Entre os adeptos do candomblé e umbanda, o mesmo ocorre: $50 \%$ deles não vêem o homossexualismo negativamente, mas $68.2 \%$ deles são contrários à divulgação do programa.

\footnotetext{
${ }^{29}$ Estatisticamente significativo ao nível de 0.000 (valor de 44.3118) com base no teste do chi-quadrado. $\mathrm{O}$ valor de $\mathrm{V}$ de Cramér foi de 0.1376 .

30 Os membros da Assembléia de Deus, mais uma vez, são os mais tradicionalistas: cerca de $83.5 \%$ se mostraram favoráveis à proibição do programa. Os menos tradicionalistas são os membros da Igreja Universal do Reino de Deus: mesmo assim, $70.4 \%$ deles consideraram correta a proibição. Todos os demais grupos também se posicionaram a favor do veto ao programa e situam-se entre esses dois pólos: batistas, 79.6\%; outras denominações pentecostais, 75.9\%; Congregação Cristã no Brasil, 75.0\%; outras denominações evangélicas, $74.4 \%$; outras igrejas não-pentecostais, $72.2 \%$. O teste de chi-quadrado apresentou nível de significância de 0.000 e o valor de 39.7989. O valor de $V$ de Cramér foi de 0.1304 .
} 


\section{Gráfico 11 - Distribuição das religiões segundo o programa de televisão que defende o casamento homossexual deve ser proibido?}

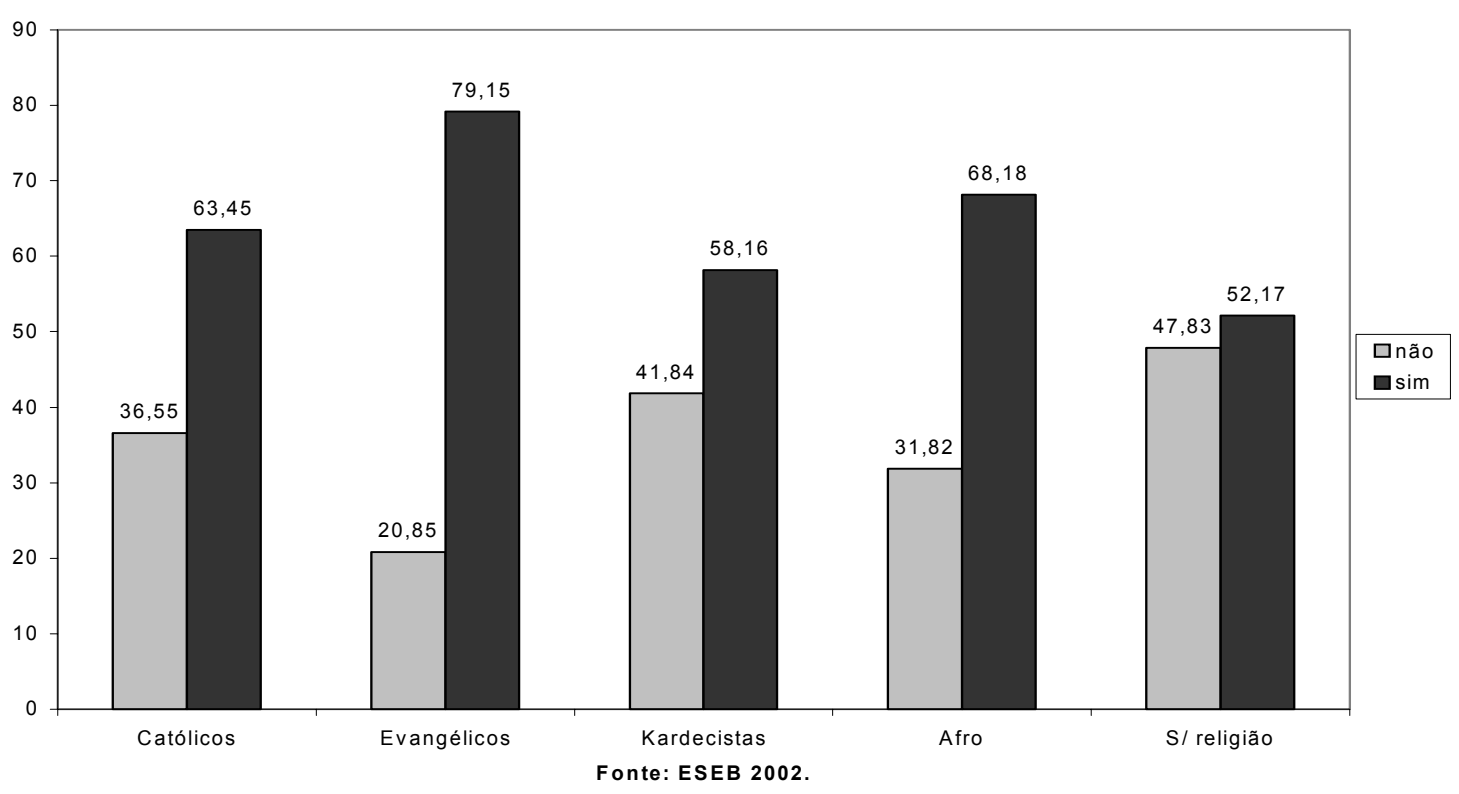

Se as posições frente ao aborto e ao homossexualismo servem como termômetros da postura dos evangélicos no campo da moral social, utilizamos a opinião em relação às greves contra o governo como indicador de sua visão diante de formas coletivas de protesto social e político. Nesse aspecto, evangélicos e

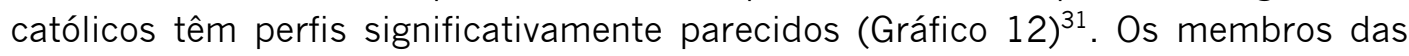
diversas denominações evangélicas são ligeiramente mais conservadores que os católicos: $39.3 \%$ deles são favoráveis à proibição total de greves contra o governo entre os católicos, a porcentagem é de 33.3\%. O posicionamento desses dois grupos contrasta bastante com a opinião dos adeptos das religiões afro-brasileiras que, em sua maioria (81.8\%), consideram que as greves contra o governo devem ser sempre permitidas ou permitidas na maioria das vezes. Entre eles, os opositores à qualquer tipo de greve contra o governo são apenas $4.5 \%$. É interessante, no entanto, lembrar que, embora tenham opiniões quase que

310 teste de chi-quadrado nível de significância de 0.000 e o valor de 37.3920 (valor de $V$ de Cramér: 0.0732). Num segundo teste a respeito da posição em relação às greves contra o governo, agregamos as opiniões em dois pólos (sempre permitidas ou permitidas na maioria das vezes vs. sempre proibidas ou proibidas na maioria das vezes). Neste caso, teste de chi-quadrado apresentou nível de significância de 0.000 e o valor de 26.8250 (valor de V de Cramér: 0.1073). 
antagônicas a respeito de greves contra o governo, os três grupos possuem um perfil educacional consideravelmente semelhante. Cerca de $72.7 \%$ dos fiéis do candomblé e da umbanda concluíram o ensino fundamental. Entre os evangélicos e católicos, essa proporção é de $75.0 \%$ e $74.4 \%$, respectivamente. Isso significa que, se os evangélicos são mais tradicionalistas (ou ligeiramente mais tradicionalistas) no que se refere à moral, eles são bastante parecidos com os católicos em relação ao seu grau de tolerância para com formas coletivas de protesto social e político,indicando que suas posturas tradicionalistas vêm acompanhadas por um maior conservadorismo político.

\section{Gráfico 12 - Distribuição das religiões segundo a posição em relação a greves contra o governo}

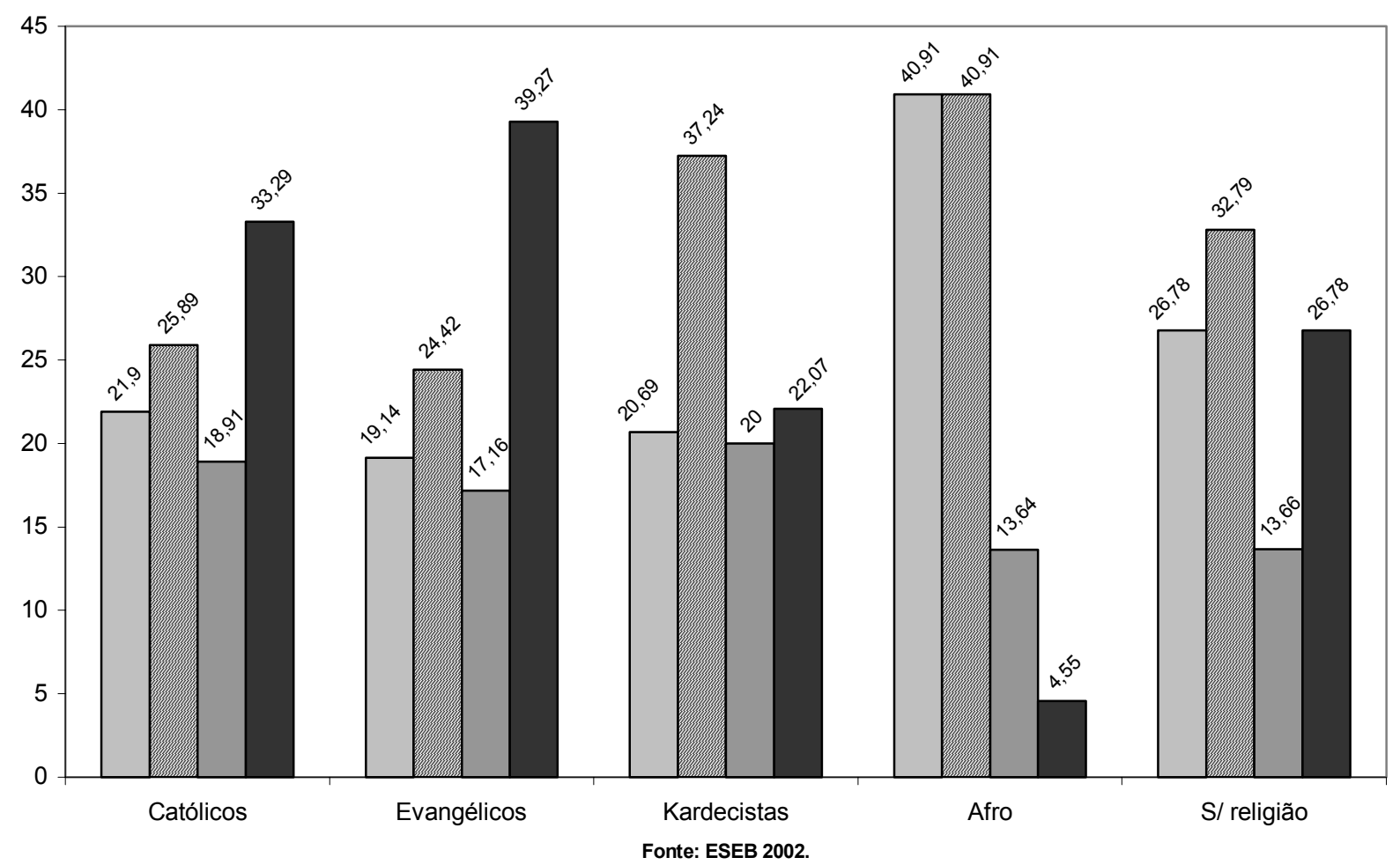


O maior tradicionalismo dos evangélicos se traduz em posições mais conservadoras no que se refere à participação do Estado na economia? A direita está historicamente ligada à defesa do direito de propriedade e da iniciativa privada, ao passo que posições esquerdistas estão associadas à manutenção do controle estatal de grande número de atividades econômicas e sociais ${ }^{32}$. Qual é a percepção do segmento evangélico em relação à presença da iniciativa privada em setores tais como saúde, aposentadoria e previdência social, e educação? Com base no seu perfil, é possível posicioná-los inequivocamente numa escala esquerdadireita?

Os dados da Tabela 12 revelam uma maioria supra-religiosa favorável à presença do Estado nas atividades de educação, saúde e aposentadoria e previdência social. Os evangélicos são o segmento que mais defende a presença da iniciativa privada no setor educacional - muito provavelmente para garantir o funcionamento de escolas privadas religiosas -; mas mesmo assim, entre eles, cerca de $72.4 \%$ se mostram favoráveis à participação exclusiva do Estado nessa atividade. Em relação ao setor da saúde, não são os evangélicos, mas os kardecistas os mais favoráveis à atuação da iniciativa privada. No que se refere à aposentadoria e previdência social, por fim, os adeptos das religiões afro-brasileiras invertem sua posição em relação à educação e saúde e se revelam os maiores defensores da iniciativa privada.

Tabela 12

Distribuição das religiões segundo o papel exclusivo do estado em algumas atividades (em \%)

\begin{tabular}{|l|c|c|c|c|}
\hline Religião & Educação & Saúde & $\begin{array}{c}\text { Aposentadoria e } \\
\text { previdência social }\end{array}$ & Bancos \\
\hline Católica & 80.0 & 82.6 & 84.2 & 57.8 \\
\hline Evangélica & 72.4 & 74.3 & 76.1 & 50.6 \\
\hline Kardecista & 73.0 & 66.7 & 74.6 & 39.7 \\
\hline Afro-brasileiras & 90.9 & 86.4 & 68.2 & 40.9 \\
\hline Sem religião & 77.8 & 79.5 & 80.3 & 47.8 \\
\hline Chi-quadrado & 0.008 & 0.000 & 0.000 & 0.001 \\
(valor) & $(13.7675)$ & $(22.8087)$ & $(20.1900)$ & $(19.6785)$ \\
V de Cramér & 0.0769 & 0.0984 & 0.0928 & 0.0922 \\
\hline
\end{tabular}

Fonte: ESEB 2002

32 Perguntados a respeito da reforma agrária no Brasil, 48.5\% dos evangélicos responderam que "o governo deve desapropriar as terras sem uso". 51.5\% deles, no entanto, se opõem à desapropriação de áreas improdutivas e acreditam que "o dono da terra deve ter o direito de querer ou não cultivar suas terras". Como esses resultados não são estatisticamente significantes, a temática da reforma agrária embora fundamental no debate entre esquerda e direita - não será explorada aqui. 
A existência de uma maioria de mais três quintos em cada grupo que se posiciona favoravelmente à participação estatal exclusiva revela que a variável religião não tem muito poder explicativo no que tange ao posicionamento numa escala estatismo vs. defesa da iniciativa privada. Apesar dessa indiferenciação, duas nuances são visíveis: os membros do kardecismo se revelaram quase que sistematicamente os mais favoráveis à presença da iniciativa privada, e os católicos os mais favoráveis à exclusividade estatal nas três atividades mencionadas. O perfil dos evangélicos, nesse sentido, não é muito claro: ou seja, seu posicionamento frente a esses três importantes tópicos não nos permite situá-los quer claramente à direita ou à esquerda.

Quando observamos a posição dos evangélicos em relação à presença da iniciativa privada no setor bancário, a análise se complica ainda mais, uma vez que esse segmento é, ao lado dos fiéis da Igreja Católica, um dos maiores defensores do exclusivismo estatal. Como esse grupo se posiciona em relação ao controle estatal de algumas atividades econômicas mais ligadas à vida cotidiana dos cidadãos brasileiros, tais como os transportes, o recolhimento do lixo e a administração de estradas e rodovias?

Em todos os grupos examinados, mais uma vez há uma maioria favorável ao controle estatal exclusivo das atividades listadas (Tabela 13). É interessante notar que, em todos os grupos, a preferência pela participação exclusiva do Estado cresce quando passamos da atividade de transportes para a coleta de lixo e, em seguida, para a administração de estradas e rodovias, dado que esses serviços compõem áreas em que a presença do Estado é percebida como crescentemente mais importante.

Tabela 13

Distribuição das religiões segundo o papel do Estado e da iniciativa privada

\begin{tabular}{|l|c|l|l|l|l|l|}
\hline Atividade & \multicolumn{3}{|l|}{ Transportes } & \multicolumn{2}{l|}{ Coleta de lixo } & \multicolumn{2}{l|}{$\begin{array}{l}\text { Administração de } \\
\text { estradas e rodovias }\end{array}$} \\
\hline Religião & $\begin{array}{l}\text { Somente } \\
\text { governo }\end{array}$ & $\begin{array}{l}\text { Somente } \\
\text { Empresas }\end{array}$ & $\begin{array}{l}\text { Somente } \\
\text { governo }\end{array}$ & $\begin{array}{l}\text { Somente } \\
\text { Empresas }\end{array}$ & $\begin{array}{l}\text { Somente } \\
\text { governo }\end{array}$ & $\begin{array}{l}\text { Somente } \\
\text { Empresas }\end{array}$ \\
\hline Católica & 59.9 & 28.6 & 75.1 & 18.1 & 79.3 & 11.9 \\
\hline Evangélica & 60.4 & 26.4 & 67.4 & 22.8 & 73.7 & 18.5 \\
\hline Kardecista & 40.6 & 35.0 & 53.5 & 34.7 & 62.9 & 23.1 \\
\hline Afro-brasileiras & 63.6 & 36.4 & 68.2 & 27.3 & 72.7 & 27.3 \\
\hline Sem religião & 56.0 & 31.9 & 71.2 & 21.7 & 71.6 & 20.8 \\
\hline $\begin{array}{l}\text { Chi-quadrado (valor) } \\
\text { V de Cramér }\end{array}$ & $0.000(33.3747)$ & $0.000(37.8341)$ & $0.000(39.2918)$ \\
\hline
\end{tabular}

Fonte: ESEB 2002 
BOHN, Simone R. Evangélicos no Brasil...

Os evangélicos não se distinguem dos demais grupos nem por um eventual elevado nível de estado-centrismo, nem pela defesa obstinada do controle exclusivo da iniciativa privada. Os católicos, por outro lado, aparecem como defensores mais árduos da presença exclusiva do Estado do que os evangélicos. Em todas as atividades, além disso, os menos favoráveis ao exclusivismo estatal são encontradas entre os kardecistas. Assim sendo, se a defesa da diminuição da participação do Estado na economia é uma das teses direitistas, então é bastante problemático vincular os evangélicos à direita do espectro político.

No interior das denominações evangélicas, os não-pentecostais claramente se diferenciam dos pentecostais no que se refere ao transporte (Tabela 14). Entre os batistas, por exemplo, apenas $31.2 \%$ consideram que essa atividade deva ser realizada exclusivamente pelo Estado, ao passo que entre os pentecostais essa porcentagem é significativamente maior: 59.2\%, Assembléia; 66.7\%, Congregação; $65.4 \%$, Universal; e $61.2 \%$, outras denominações pentecostais. No que tange às outras duas atividades, no entanto, há uma maioria pró-exclusivismo estatal. 0 destaque recai sobre a Igreja Universal do Reino de Deus: um pouco mais de um terço dos seus membros consideram que somente a iniciativa privada deveria ser responsável pela coleta de lixo (38.5\%) e pela administração de estradas e rodovias (34.6\%).

Tabela 14

Distribuição dos evangélicos segundo opinião sobre o papel do Estado e da iniciativa privada

\begin{tabular}{|l|c|l|l|l|l|l|}
\hline Atividade & \multicolumn{2}{|l|}{ Transportes } & \multicolumn{2}{l|}{ Coleta de lixo } & \multicolumn{2}{l|}{$\begin{array}{l}\text { Administração de } \\
\text { estradas e rodovias }\end{array}$} \\
\hline Denominação & $\begin{array}{l}\text { Somente } \\
\text { governo }\end{array}$ & $\begin{array}{l}\text { Somente } \\
\text { Empresas }\end{array}$ & $\begin{array}{l}\text { Somente } \\
\text { governo }\end{array}$ & $\begin{array}{l}\text { Somente } \\
\text { Empresas }\end{array}$ & $\begin{array}{l}\text { Somente } \\
\text { governo }\end{array}$ & $\begin{array}{l}\text { Somente } \\
\text { Empresas }\end{array}$ \\
\hline Assembléia & 59.2 & 25.0 & 72.5 & 17.5 & 74.2 & 13.3 \\
\hline Congregação & 66.7 & 27.8 & 71.0 & 26.3 & 78.9 & 21.0 \\
\hline Universal & 65.4 & 23.1 & 53.8 & 38.5 & 61.5 & 34.6 \\
\hline Outras pent. & 61.2 & 26.2 & 60.0 & 26.2 & 77.8 & 18.5 \\
\hline Batista & 31.2 & 29.2 & 59.2 & 22.4 & 65.3 & 14.3 \\
\hline Outras não-pent. & 45.9 & 35.1 & 55.3 & 31.6 & 57.9 & 26.3 \\
\hline Não especificou & 61.1 & 27.8 & 68.4 & 21.0 & 67.6 & 21.6 \\
\hline Chi-quadrado (valor) & $0.000(43.3137)$ & $0.002(34.3673)$ & $0.000(38.4975)$ \\
\hline
\end{tabular}

Fonte: ESEB 2002 
O tema da intervenção direta do Estado no funcionamento global da economia foi tratado a partir do exame de duas questões. A primeira diz respeito à violação da relação entre demanda e oferta como determinante dos valores finais das mercadorias e examina a concordância do entrevistado em relação ao controle de preços por parte do Estado (Tabela 15). Uma maioria - supra-religiosa - se forma na defesa da intervenção estatal na política de preços. Os evangélicos são os que mais concordam com uma política dessa natureza ( $80.3 \%$ ), ao passo que a maior discordância advém dos adeptos das religiões afro-brasileiras (36.4\%). É desnecessário enfatizar a similaridade dos perfis educacionais desses dois grupos.

A maioria em favor da intervenção do Estado é ainda mais pronunciada no que se refere a um segundo tópico: o socorro financeiro a empresas em dificuldades. Mais de $70 \%$ dos membros de todos os grupos se mostram favorável a este tipo de ajuda estatal. Os evangélicos são os mais entusiastas em relação ao tema, seguidos de perto, uma vez mais, pelos católicos. Os adeptos do candomblé e umbanda são os menos favoráveis a esse tipo de iniciativa.

Tabela 15

Intervenção do Estado na economia, segundo religiões (em \%)

\begin{tabular}{|l|c|c|c|c|}
\hline Atividade & \multicolumn{2}{|c|}{$\begin{array}{l}\text { Governo deve controlar os preços de } \\
\text { todos os produtos vendidos no Brasil }\end{array}$} & \multicolumn{2}{l|}{$\begin{array}{l}\text { overno deve socorrer empresas } \\
\text { em dificuldade }\end{array}$} \\
\hline Religião & Concorda & Discorda & Concorda & Discorda \\
\hline Católica & 79.1 & 20.9 & 82.0 & 17.1 \\
\hline Evangélica & 80.8 & 19.2 & 86.1 & 13.2 \\
\hline Kardecista & 69.2 & 30.8 & 73.6 & 24.3 \\
\hline Afro-brasileiras & 63.6 & 36.4 & 72.7 & 27.3 \\
\hline Sem religião & 65.0 & 35.0 & 72.4 & 24.9 \\
\hline $\begin{array}{l}\text { Chi-quadrado (valor) } \\
\text { V de Cramér }\end{array}$ & \multicolumn{2}{|c|}{$0.000(28.6757)$} & $0.001(25.5291)$ \\
\hline
\end{tabular}

Fonte: ESEB 2002

O que os dados dessa seção indicam? Em primeiro lugar, conforme afirma a literatura, os fiéis evangélicos são realmente mais tradicionalistas: isto é, se revelam como defensores mais árduos da moral social e da aplicação estrita dos valores desse código na regulação da vida coletiva. Por outro lado, esse tradicionalismo não se traduz diretamente num conservadorismo político: seu grau de oposição em relação a greves contra o governo é similar ao encontrado entre os católicos. Seu posicionamento frente a tópicos relativos à participação da iniciativa privada e à intervenção direta do Estado no funcionamento da economia mostra, além disso, que os evangélicos não podem ser categorizados inequivocamente como pertencendo a um dos pólos do eixo esquerda-direita. 
BOHN, Simone R. Evangélicos no Brasil...

Essa categorização pode ser feita quando examinamos as escolhas eleitorais e partidárias feitas pelos evangélicos? Este é o tema da próxima seção.

\section{Alguns determinantes do comportamento eleitoral do público evangélico}

Quais são os principais determinantes do comportamento eleitoral dos evangélicos? Quais têm sido suas escolhas eleitorais e partidárias?

Perguntados acerca do seu voto no primeiro turno na eleição presidencial de 2002, a maioria dos evangélicos (51.3\%) afirmou ter votado em Anthony Garotinho

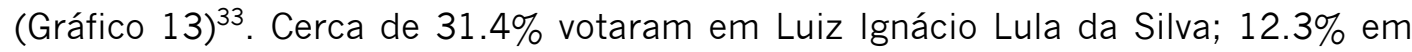
José Serra e $3.4 \%$ em Ciro Gomes. É curioso notar que a segunda maior votação declarada de Garotinho aparece entre os kardecistas - grupo que, como vimos, possui, ao contrário dos evangélicos, os maiores níveis de renda e escolaridade. Entre os católicos e as pessoas sem religião, cerca de $56 \%$ optaram pela candidatura Lula. Essa escolha foi massiva entre os fiéis do candomblé e da umbanda: $83.3 \%$ deles votaram no candidato do PT.

Gráfico 13 - Distribuição das religiões segundo o voto no primeiro turno na eleição presidencial de 2002

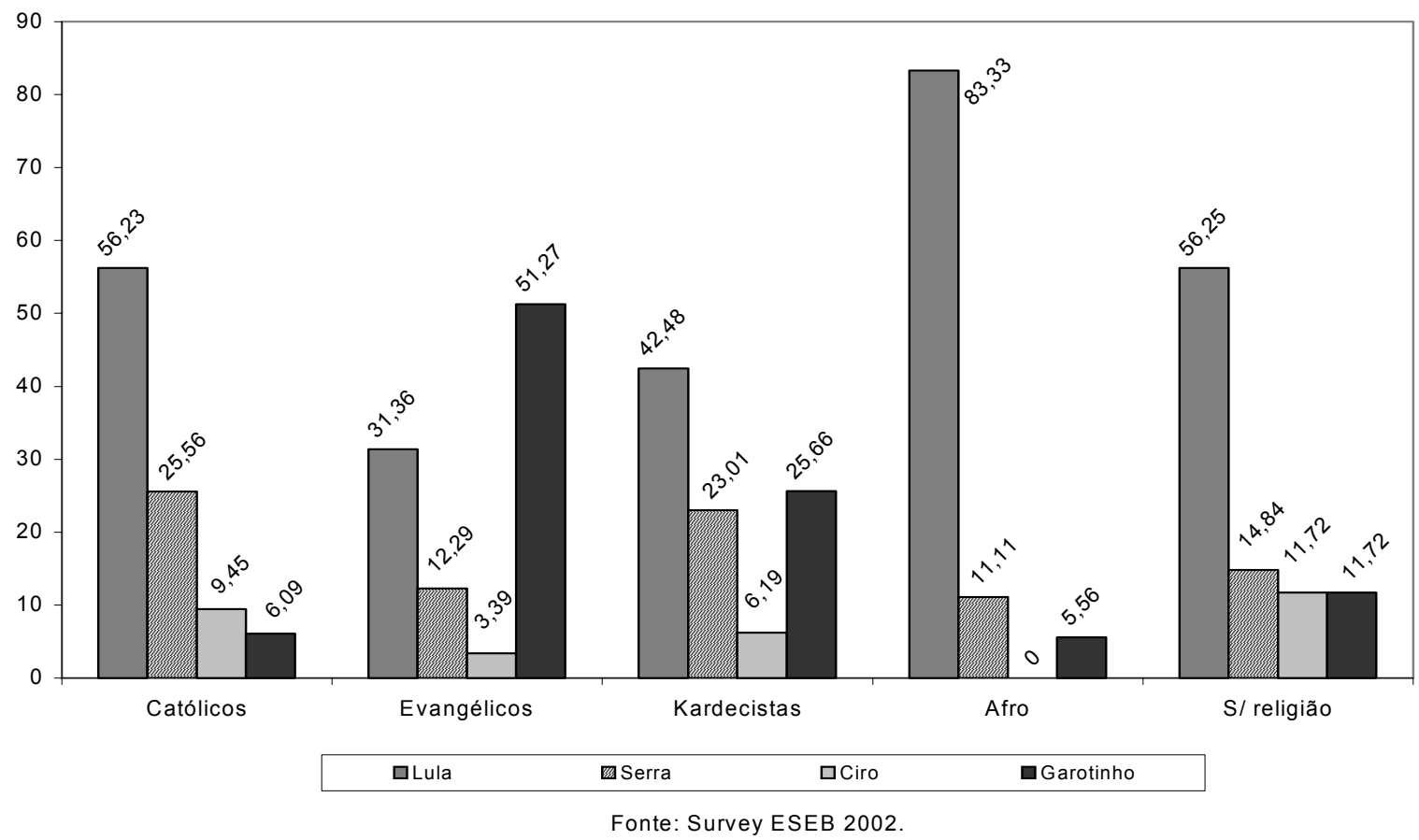

33 O teste de chi-quadrado apresentou o nível de significância de 0.000 e o valor de 396.9077. O valor do $\checkmark$ de Cramér foi de 0.2272 . 
A idéia de que a filiação evangélica tende a gerar preferências por determinadas opções políticas não pode ser completamente rejeitada quando observamos o padrão de voto declarado no interior do segmento evangélico. A preferência pela candidatura de Anthony Garotinho perpassou todas as denominações evangélicas, com exceção dos membros da Congregação Cristã no Brasil (Tabela 16). Entre os membros dessa última confissão, Garotinho foi a terceira opção $(16.0 \%)$ atrás de Lula $(56.0 \%)$ e de Serra $(24.0 \%)^{34}$. Os maiores apoiadores dessa candidatura, por outro lado, foram os fiéis da Assembléia de Deus: seis em cada dez votaram no candidato que pertencia ao PSB. No padrão de voto declarado não há diferenças significativas entre pentecostais e nãopentecostais, assim como não existe homogeneidade de comportamento no interior desses dois grupos.

\section{Tabela 16}

\section{Distribuição dos evangélicos segundo o voto declarado no primeiro turno} da eleição presidencial de 2002*

\begin{tabular}{|l|r|r|r|c|c|}
\hline Denominação & Lula (\%) & Serra (\%) & Ciro (\%) & Garotinho (\%) & $\begin{array}{l}\text { Em branco } \\
\text { \& nulo (\%) }\end{array}$ \\
\hline Assembléia & 22.1 & 11.6 & 3.2 & 62.1 & 1.0 \\
\hline Congregação & 56.0 & 24.0 & 4.0 & 16.0 & 0 \\
\hline Universal & 33.3 & 9.5 & 4.8 & 52.4 & 0 \\
\hline Outras pentecostais & 35.0 & 15.0 & 5.0 & 40.0 & 5.0 \\
\hline Batista & 37.5 & 10.0 & 2.5 & 50.0 & 0 \\
\hline Outras não-pentecostais & 11.1 & 29.6 & 11.1 & 48.1 & 0 \\
\hline Não especificou & 37.0 & 3.7 & 0 & 59.3 & 0 \\
\hline
\end{tabular}

*Nível de significância de 0.000 no teste de qui-quadrado (valor de 469.0380); V de Cramér: 0.2469.

Fonte: ESEB 2002

No que se refere ao segundo turno da eleição presidencial de 2002, católicos, evangélicos e kardecistas têm um padrão de voto declarado bastante semelhante: mais de 60\% deles votaram em Lula e cerca de 30\% votaram em Serra (Gráfico 14) ${ }^{35}$. Esses números mostram que, entre os evangélicos, a candidatura Lula teve um aumento de 30 pontos percentuais, ao passo que a candidatura Serra aumentou somente 22 pontos percentuais. Ou seja, Lula atraiu aproximadamente $53 \%$ dos eleitores evangélicos que haviam votado em Ciro, Garotinho, nulo ou em branco no primeiro turno. Esse comportamento contrasta bastante com o padrão de

\footnotetext{
${ }^{34}$ De acordo com Pierucci \& Mariano (1992), as autoridades religiosas da Congregação Cristã no Brasil pregam uma separação estrita entre religião e política.

$35 \mathrm{O}$ teste de chi-quadrado apresentou nível de significância de 0.001 e o valor de 25.5519. O valor do V de Cramer foi de 0.0814 .
} 
votação dos evangélicos nas eleições de 1989 e 1994, quando houve, entre eles, considerável rejeição da candidatura Lula.

\section{Gráfico 14 - Distribuição das religiões segundo o voto no segundo turno na eleição presidencial de 2002}

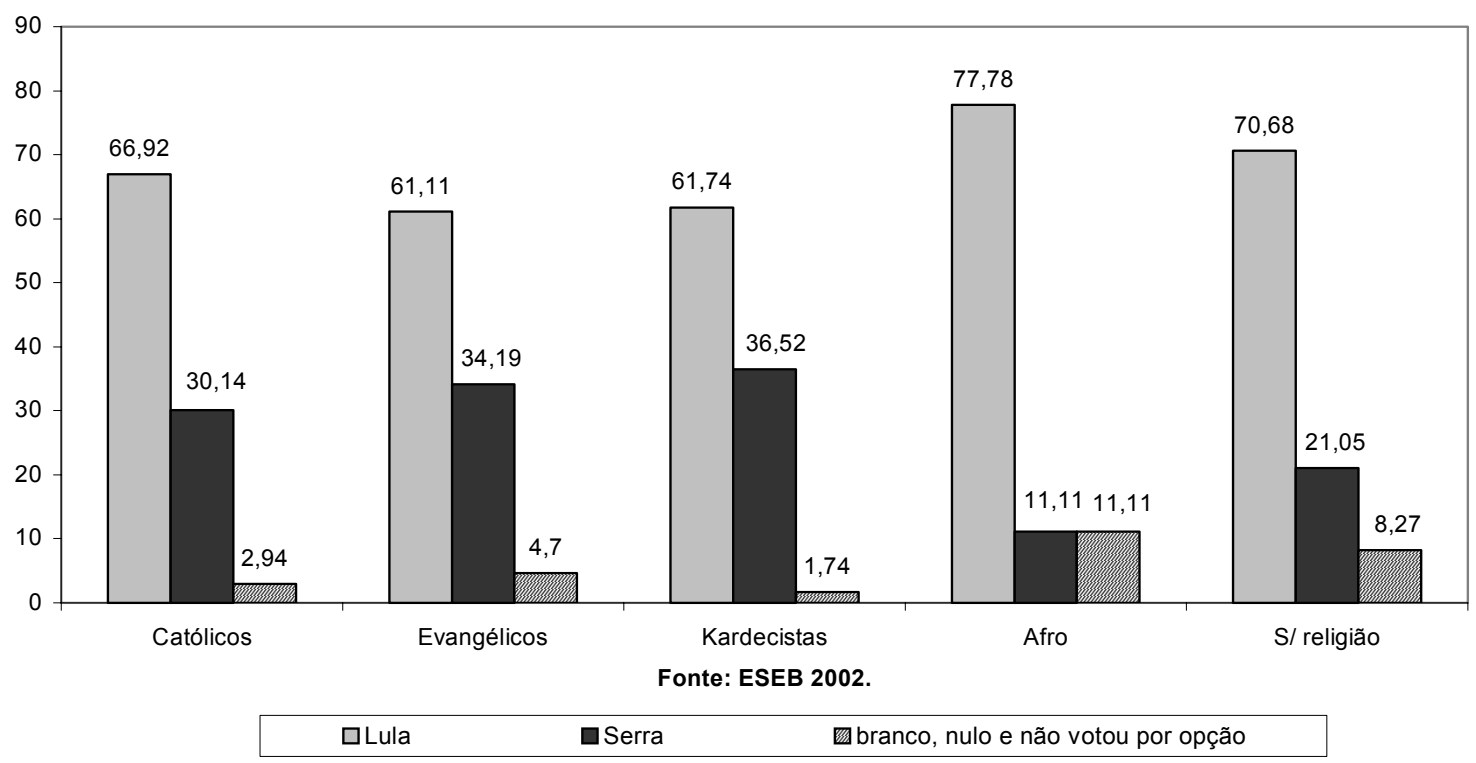

A Igreja Universal e as outras denominações não especificadas foram as religiões evangélicas em que houve mais alterações positivas na candidatura Lula. Os membros da Assembléia de Deus praticamente se dividiram ao meio: entre eles, Lula acrescentou à sua carteira de votos 32.8 pontos percentuais e Serra 31.2. 0 mesmo ocorreu entre os fiéis da Igreja Batista: entre eles, Lula recebeu a mais 27.5 pontos percentuais dos votos; e Serra, 25. Os membros da Congregação Cristã no Brasil representam um caso diferente. Entre eles, Lula recebeu $56 \%$ de votos no primeiro turno e $57.7 \%$ no segundo. Serra, ao contrário, recebeu $24 \%$ no primeiro turno e $34.6 \%$ no segundo. 
Tabela 17

Distribuição dos evangélicos segundo o voto declarado no segundo turno da eleição de $2002 *$

\begin{tabular}{|l|c|c|c|}
\hline Denominação & Lula (\%) & Serra (\%) & Em branco \& nulo (\%) \\
\hline Assembléia & 54.9 & 42.9 & 2.2 \\
\hline Congregação & 57.7 & 34.6 & 7.7 \\
\hline Universal & 76.2 & 23.8 & 0 \\
\hline Outras pentecostais & 58.1 & 32.3 & 9.7 \\
\hline Batista & 65.0 & 35.0 & 0 \\
\hline Outras não-pentecostais & 50.0 & 50.0 & 0 \\
\hline Não especificou & 84.0 & 12.0 & 4.0 \\
\hline
\end{tabular}

* Nível de significância de 0.009 no teste de qui-quadrado (valor de 29.6303); V de Cramér: 0.0.0876).

Fonte: ESEB 2002

Quais foram os determinantes dessas escolhas de católicos, kardecistas, adeptos do candomblé e umbanda, e sobretudo dos evangélicos? Com o objetivo de mapear os principais determinantes da escolha de candidaturas, os entrevistados foram expostos a doze de fontes de informação a respeito dos candidatos a presidente da República em $2002^{36}$. Para a maioria dos grupos, os debates entre os candidatos na televisão constituem-se num importante veículo para a decisão do voto: em torno de um terço deles elegeu essa como a mais importante variável (Gráfico 15) ${ }^{37}$. Em segundo e terceiro lugares, aparecem, respectivamente, a propaganda política na televisão e conversas com amigos e parentes a respeito dos candidatos.

\footnotetext{
36 As opções apresentadas foram as seguintes: conversas com colegas de trabalho ou da escola; propaganda política na televisão; notícias sobre os candidatos nos jornais; notícias sobre os candidatos no rádio; notícias sobre os candidatos na televisão; ouvir os candidatos em comício; informações da igreja sobre os candidatos; informações de associações de moradores sobre os candidatos; os resultados das pesquisas eleitorais; debates entre candidatos na televisão; conversas com amigos e pessoas da família; propaganda política no rádio. Os entrevistados receberam um cartão com essas dozes alternativas e foram solicitados a indicar as três mais importantes em ordem decrescente.

$37 \mathrm{O}$ teste de chi-quadrado apresentou nível de significância de 0.000 e o valor de 115.6701 . O valor do V de Cramér foi de 0.1278 .
} 


\section{Gráfico 15 - Distribuição das religiões segundo as determinantes da escolha do candidato presidencial em 2002}

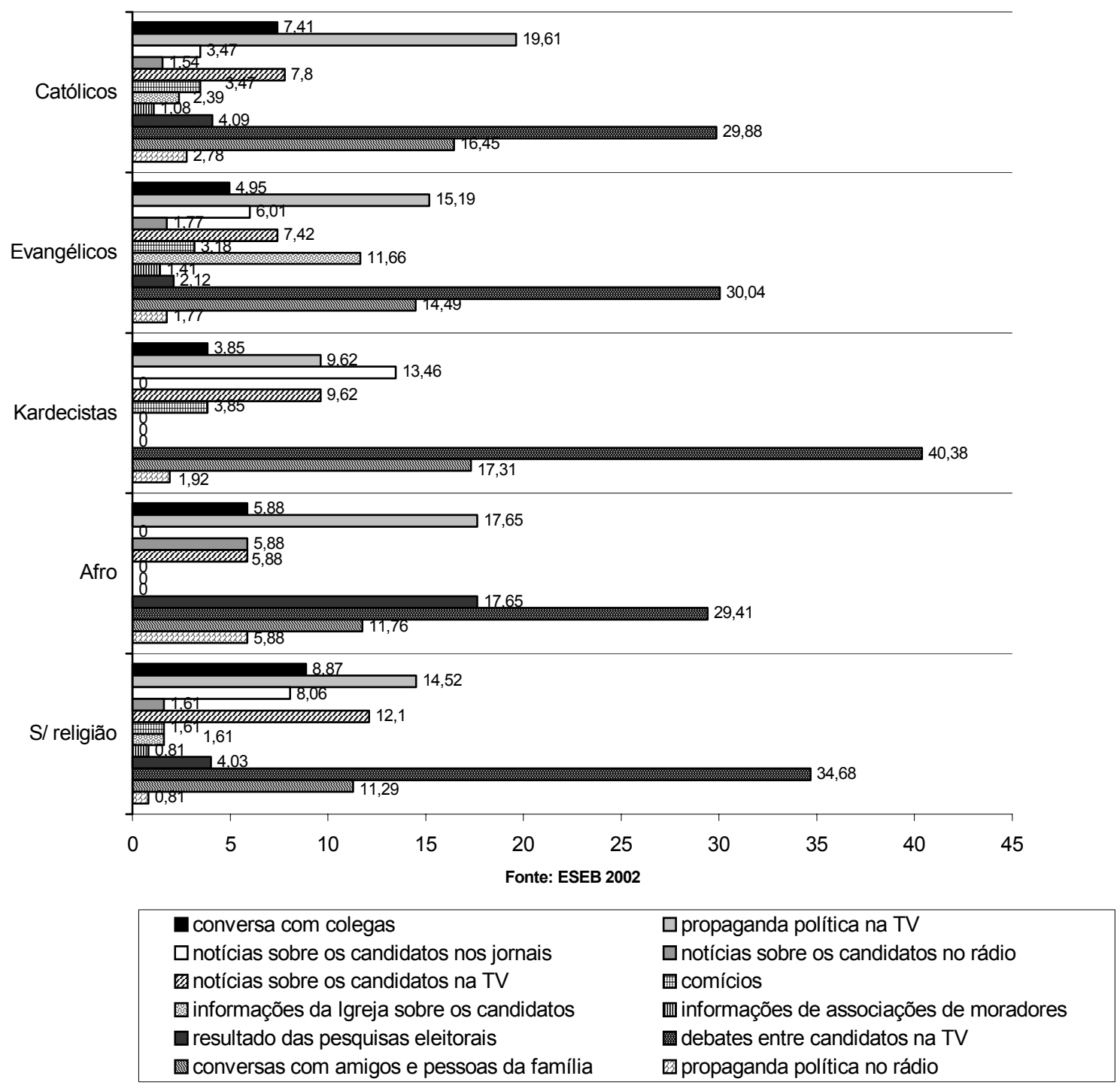


De todos estes, apenas dois produziram distinções estatisticamente significativas entre os grupos examinados: notícias nos jornais a respeito das diferentes candidaturas e informações da igreja sobre os candidatos ${ }^{38}$. Os adeptos do kardecismo se destacam pela importância atribuída às notícias veiculadas nos jornais sobre os candidatos a presidente em 2002 (Gráfico 16) ${ }^{39}$. Cerca de 13.2\% deles mencionaram essa fonte como a mais importante para a decisão do voto. Entre os demais grupos, essa fonte é bem menos decisiva: o percentual indicado entre os kardecistas é quase o dobro do existente entre as pessoas sem vínculos religiosos (7.9\%) e entre os evangélicos (6.0\%); e quase quatro vezes maior que a porcentagem encontrada entre os católicos (3.4\%). Nenhum dos membros do candomblé e umbanda mencionou essa fonte como sendo a mais importante.

A informações da Igreja sobre os candidatos afetam mais o eleitorado filiado às denominações evangélicas. Aproximadamente $11.6 \%$ deles mencionaram essa fonte como sendo a mais importante na decisão acerca da escolha do candidato a presidente. Uma porcentagem bem inferior de católicos (2.4\%) citou a igreja como a mais importante. Para kardecistas e adeptos das religiões afro-brasileiras, esse elemento não se constitui num determinante na decisão do voto. Esses números significam que, embora todos os grupos se unifiquem na eleição dos debates na televisão como fator mais importante na escolha de candidatos, o peso atribuído às informações advindas da igreja é o elemento que distingue os evangélicos dos demais grupos, inclusive os católicos.

\footnotetext{
38 As doze fontes de informação (ou determinantes do voto) listadas na nota 33 foram trabalhadas de duas formas. Num primeiro momento, agrupamos todas elas numa única variável e observamos quais delas foram listadas como sendo a mais importante para cada um dos grupos. Esses resultados que apareceram no Gráfico 15 revelam, portanto, as similaridades entre os diferentes grupos. Num segundo momento, buscamos o que é distintivo de cada grupo. A fim de verificar se há diferenças estatisticamente significativas na importância atribuída a essas fontes de informação por cada um dos cinco grupos, as doze opções foram analisadas individualmente. O Gráfico 16 resume os resultados dessa segunda análise. O mesmo procedimento foi utilizado na análise dos determinantes da escolha dos partidos políticos.

39 No caso do item "notícias sobre os candidatos nos jornais", o teste de chi-quadrado apresentou nível de significância de 0.000, o valor de 29.8782 e o valor do V de Cramér foi de 0.0750. Para o outro item ("informações da igreja sobre os candidatos"), os mesmos indicadores apresentaram os seguintes números: 0.000, 95.5821, e 0.1341.
} 
Gráfico 16 - Distribuição das religiões segundo o critério mais importante para a escolha de candidato a presidente

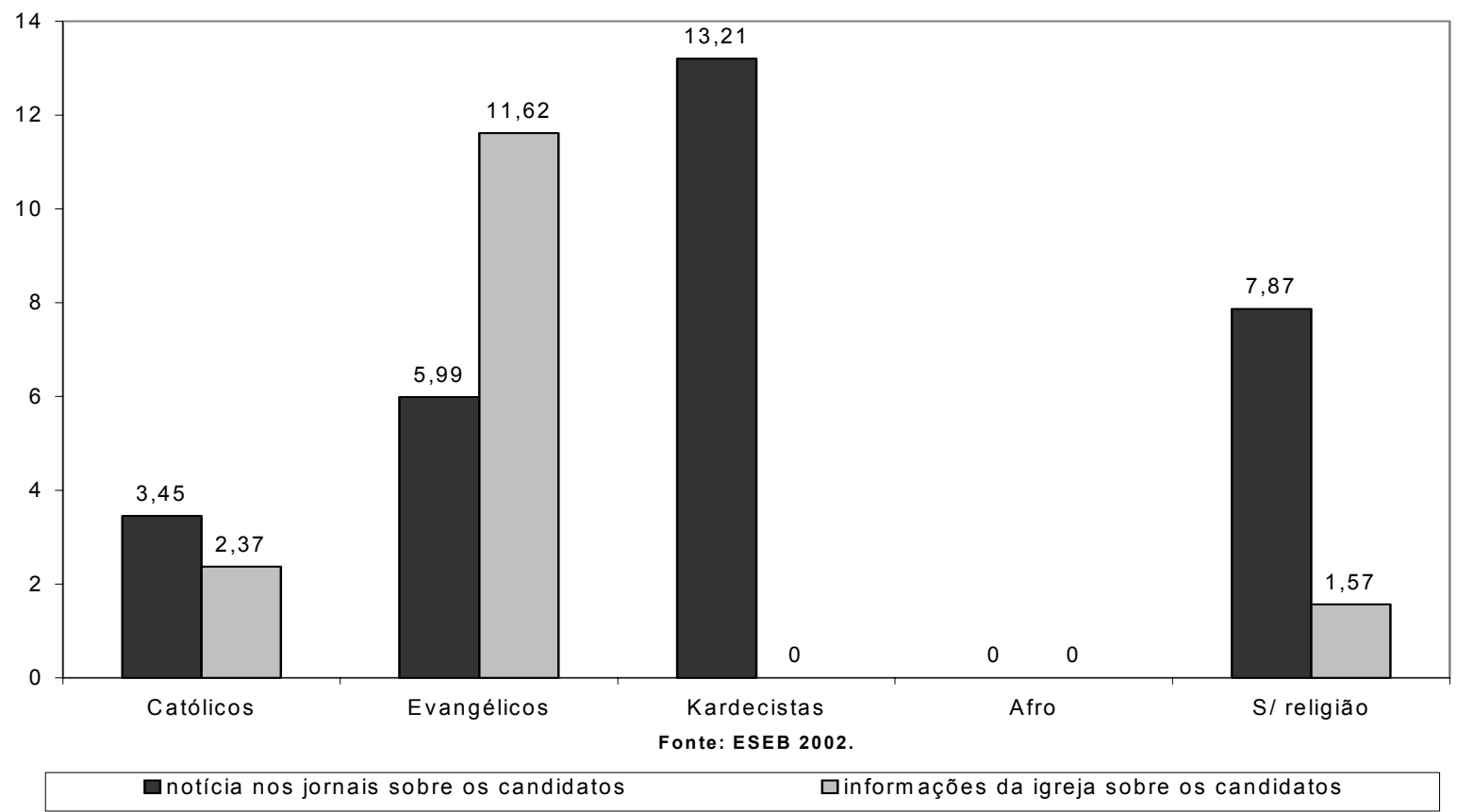

Quais são os partidos políticos de preferência dos evangélicos e como são escolhidos? Com exceção dos adeptos do kardecismo, a maioria em todos os grupos aqui examinados não se identifica com nenhum partido político (Tabela 18). Os menores níveis de identificação partidária são encontrados entre os evangélicos. Apenas $32.3 \%$ se sentem representados por algum partido. Entre os indivíduos sem religião, esse número é praticamente igual: 32.6\%. Católicos e membros do candomblé e da umbanda têm um perfil similar a esse respeito: 39.2\% e 40.9\%, respectivamente, consideram que algum partido específico representa o que eles pensam a respeito do mundo político. 
As porcentagens melhoram significativamente quando deixamos de lado a identificação partidária e passamos para a simpatia partidária ${ }^{40}$. Perguntados se gostam de algum partido, a maioria entre os católicos, kardecistas, candombleístas e umbandistas respondeu positivamente. Entre esses três grupos, as porcentagens são bastante similares. Novamente os evangélicos e as pessoas sem religião são os que menos dizem gostar de algum partido político ${ }^{41}$. Em todos os segmentos, a proporção de indivíduos que gosta de alguma agremiação é superior aos que se sentem identificados aos partidos.

Tabela 18

Atitude em relação aos partidos políticos

\begin{tabular}{|l|c|c|c|c|}
\hline & \multicolumn{2}{|l|}{ Identificação partidária } & \multicolumn{2}{l|}{ Simpatia partidária } \\
\hline Religião & Não & Sim & Não & Sim \\
\hline Católica & 55.7 & 39.2 & 47.7 & 52.3 \\
\hline Evangélica & 65.1 & 32.3 & 59.3 & 40.7 \\
\hline Kardecista & 49.2 & 50.8 & 46.0 & 54.0 \\
\hline Afro-brasileiras & 59.1 & 40.9 & 45.5 & 54.6 \\
\hline Sem religião & 64.1 & 32.6 & 60.0 & 40.0 \\
\hline $\begin{array}{l}\text { Chi-quadrado (valor) } \\
\text { V de Cramér }\end{array}$ & $\begin{array}{c}0.002(24.8545) \\
0.0721\end{array}$ & \multicolumn{2}{c|}{$0.000(24.8515)$} \\
\hline
\end{tabular}

Fonte: ESEB 2002

40 Como indicação da existência ou não de identificação partidária, utilizamos a seguinte questão: "Existe algum partido político que representa a maneira como o(a) Sr(a) pensa?". Já para a aferição do que estamos denominando de "simpatia partidária", a pergunta selecionada foi: "De um modo geral, existe algum partido político que o(a) Sr(a) goste?"

${ }^{41}$ Entre as denominações evangélicas, não há distinções claras entre pentecostais e não-pentecostais. Os dois grupos com as menores proporções dos que dizem gostar de algum partido político são Congregação Cristã no Brasil (27.8\%) e Igreja Universal do Reino de Deus (29.6\%). Entre as demais denominações, quatro em cada dez evangélicos gostam de algum partido: Assembléia, 41.5\%; Batista, 45.1\%, outras pentecostais, 41.0\%; outras não-pentecostais, 43.2\%; outras evangélicas, $48.7 \%$. 0 teste de chi-quadrado apresentou nível de significância de 0.006 e o valor de 19.6813. 
BOHN, Simone R. Evangélicos no Brasil...

Com quais partidos políticos os diversos grupos se identificam? E quais são os que eles rejeitam? Em todos os grupos, a maior minoria se agrega em torno da preferência pelo Partido dos Trabalhadores. Esse grau de identificação é menor no caso dos evangélicos: $20.2 \%$ - em comparação com os $23.4 \%$ dos católicos, $23.6 \%$ das pessoas sem vínculos religiosos, os $31.8 \%$ dos adeptos das religiões afrobrasileiras e $36.7 \%$ dos kardecistas.

Tabela 19

Identificação partidária e religiões brasileiras (em \%)*

\begin{tabular}{|l|c|c|c|c|c|c|c|}
\hline Religião & PDT & PT & PTB & PMDB & PFL & PSDB & Outros \\
\hline Católica & 0.4 & 23.4 & 0.4 & 5.1 & 2.3 & 3.5 & 1.5 \\
\hline Evangélica & 0.3 & 20.2 & 0.8 & 2.6 & 1.6 & 2.4 & 1.6 \\
\hline Kardecista & 3.3 & 36.7 & 1.7 & 1.7 & 1.7 & 3.3 & 0 \\
\hline Afro-brasileiras & 0 & 31.8 & 0 & 0 & 4.5 & 0 & 4.5 \\
\hline Sem religião & 1.1 & 23.6 & 0 & 0.5 & 1.1 & 2.7 & 1.6 \\
\hline
\end{tabular}

*Nível de significância de 0.013 no teste de qui-quadrado (valor de 47.2861); V de Cramér: 0.0714.

Fonte: ESEB 2002

Se as preferências não são muito distingüíveis quando examinamos os partidos com os quais os entrevistados se identificam, elas se tornam um pouco menos obscuras quando analisamos as agremiações partidárias mais rejeitadas pelos membros de cada um desses grupos (Gráfico 17$)^{42}$. O PFL é o partido mais rejeitado por três grupos: adeptos das religiões afro-brasileiras (66.7\%), kardecistas (55.9\%) e pessoas sem vínculos religiosos (55.7\%). Além disso, ele é o segundo partido mais rejeitado pelos católicos (45.5\%) e o terceiro, pelos evangélicos (43.9\%). Neste último grupo religioso, os dois partidos mais rejeitados são PDT (45.5\%) e PTB (45.1\%). O Partido Trabalhista Brasileiro é também a legenda mais rejeitada pelos fiéis da Igreja Católica. Em todos os grupos, o Partido dos Trabalhadores aparece como o partido menos rejeitado, sobretudo no caso dos membros do candomblé e umbanda. Esses números significam que, embora, entre os evangélicos, a maior minoria se identifique com o PT, a grande maioria deles não possui nenhuma preferência partidária. De fato, entre todos os grupos, os evangélicos são os que menos se identificam com alguma agremiação partidária. Ou seja, apesar de terem se mostrado entusiastas em relação a algumas candidaturas - como a de Anthony Garotinho na eleição presidencial de 2002 -, os

42 Os níveis de significância (valor) e $\mathrm{V}$ de Cramér foram, respectivamente, os seguintes: PT, 0.000 (28.3166), 0.0791; PDT, 0.014 (25.2526), 0.0603; PSDB, 0.006 (27.6760), $0.0632 ;$ PFL, 0.000 (36.9915), 0.0730; PMDB, 0.002 (31.3071), 0.0671; PTB, 0.003 (29.7579), 0.0657. 
evangélicos não demonstram atitude semelhante em relação a nenhum partido político. É bastante problemático, portanto, utilizar seu padrão de preferência partidária para posicioná-los numa escala ideológica.

Gráfico 17

Distribuição das religiões segundo os partidos que o entrevistado não gosta

(\% de citação - partidos individualmente expostos ao entrevistado)

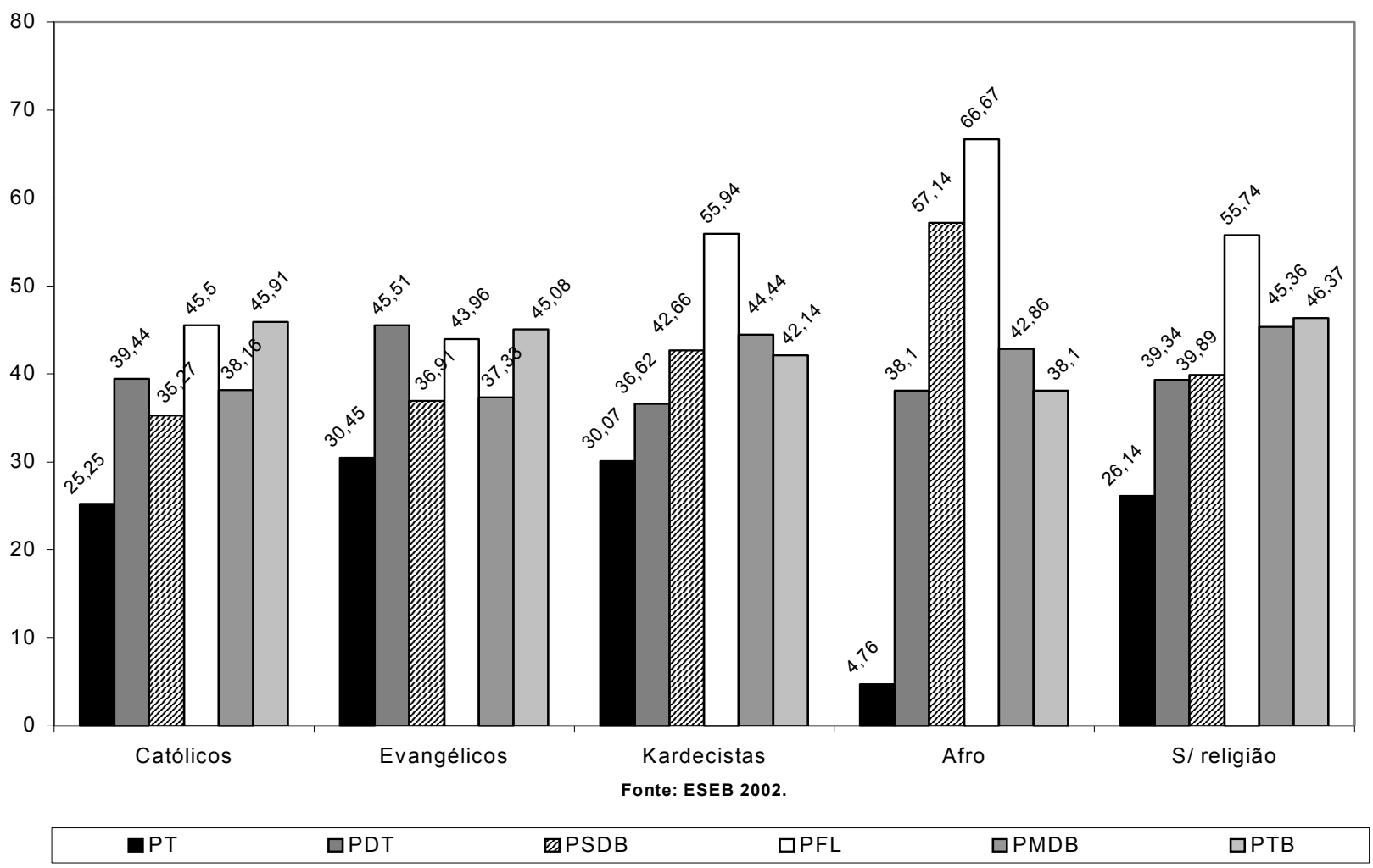

Quando perguntados acerca de quais variáveis são importantes na escolha de um partido, a maioria em cada um dos grupos apontou a honestidade dos membros da legenda (Tabela 20). O segundo elemento mencionado como sendo mais importante pela maioria das religiões consiste no programa do partido. A atuação passada dos representantes da agremiação aparece em terceiro plano para a maioria dos grupos (kardecistas, pessoas sem religião e adeptos do candomblé e umbanda). Por fim, a presença de amigos e parentes no partido é pouco determinante para todas as religiões. 
Tabela 20

Determinantes da escolha do partido político *

\begin{tabular}{|l|c|c|c|c|c|}
\hline Religião & Católica & Evangélica & Kardecista & $\begin{array}{l}\text { Afro- } \\
\text { brasileiras }\end{array}$ & Sem religião \\
\hline Programa do partido & 15.6 & 13.0 & 30.5 & 15.0 & 18.9 \\
\hline Ser um partido de gente honesta & 59.7 & 51.8 & 47.5 & 60.0 & 60.6 \\
\hline $\begin{array}{l}\text { Atuação passada de seus } \\
\text { representantes }\end{array}$ & 7.0 & 9.4 & 11.9 & 10.0 & 8.8 \\
\hline $\begin{array}{l}\text { O tipo de pessoa que o partido } \\
\text { representa }\end{array}$ & 6.9 & 5.0 & 8.5 & 10.0 & 6.5 \\
\hline Ter amigos e parentes no partido & 3.1 & 2.2 & 1.7 & 0.0 & 2.9 \\
\hline $\begin{array}{l}\text { Ser apoiado por autoridades } \\
\text { religiosas }\end{array}$ & 7.7 & 18.6 & 0.0 & 5.0 & 2.4 \\
\hline
\end{tabular}

* Nível de significância de 0.000 no teste de chi-quadrado (valor: 77.5929); V de Cramér: 0.0958.

Fonte: ESEB 2002

Quais critérios, no entanto, distinguem claramente os diversos grupos ${ }^{43}$ ? Apenas dois: o programa do partido, que separa dos kardecistas dos demais segmentos, e o apoio de autoridades religiosas, que singulariza o eleitorado evangélico. O programa partidário é o critério fundamental para a escolha do partido político no caso de $30.5 \%$ dos kardecistas ${ }^{44}$. Evidentemente, esta preferência se coaduna com o nível de escolaridade desse grupo. Esse elemento é também importante, embora em graus diferenciados para os demais grupos: pessoas sem religião (19.3\%); católicos (15.6\%); adeptos das religiões afrobrasileiras (14.3\%) e evangélicos (12.5\%).

\footnotetext{
43 Observe nota 35.

440 teste de chi-quadrado apresentou nível significância de 0.005 (valor de 22.1918); valor de Cramér's $\checkmark$ foi de 0.0720 .
} 


\section{Gráfico 18 - Distribuição das religiões segundo os critérios para a seleção de um partido político}

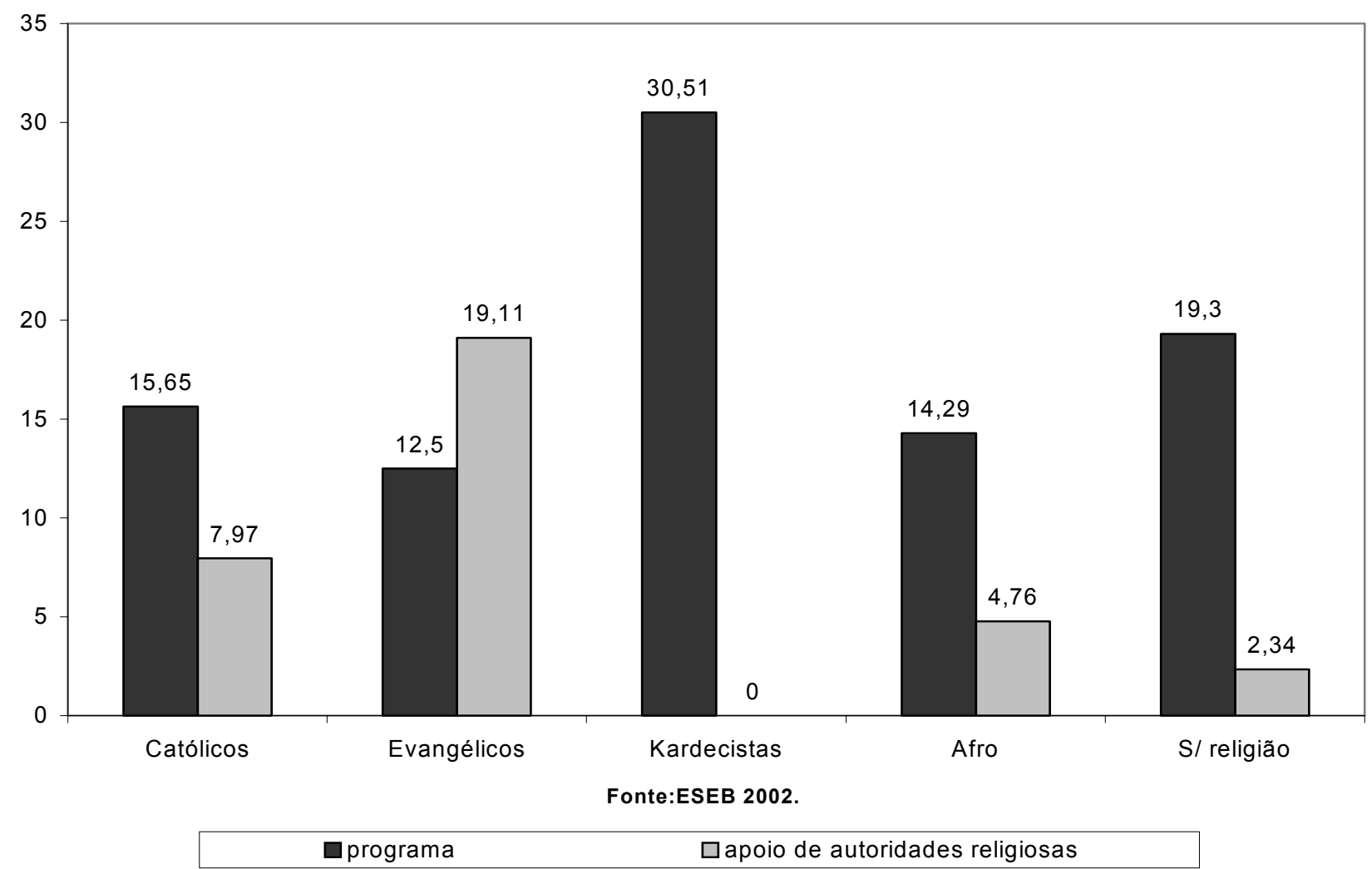

O apoio de autoridades religiosas, por sua vez, é o fator que distingue o segmento evangélico dos demais grupos ${ }^{45}$. Cerca de $19.1 \%$ deles elegeram esse quesito como critério fundamental para a decisão acerca da escolha partidária. 0 que importa salientar é a magnitude desse valor na comparação com os demais grupos religiosos. Pode-se dizer que a importância atribuída, pelos evangélicos, ao apoio de autoridades da Igreja é mais de duas vezes maior que o peso dado pelos católicos a esse mesmo fator; quatro vezes maior que do que o peso dado pelos membros do candomblé e umbanda; e, por razões óbvias, mais de oito vezes maior do que o impacto dessa fonte para a decisão das pessoas sem religião. Entre os kardecistas, essa variável simplesmente não pesa na escolha partidária.

450 teste de chi-quadrado apresentou nível significância de 0.000 (valor de 76.7291); valor de Cramér's $\checkmark$ foi de 0.1338 . 
BOHN, Simone R. Evangélicos no Brasil...

\section{Considerações finais}

Procuramos testar, três diagnósticos sobre o eleitorado evangélico no Brasil: sua associação com condições indicativas de pobreza, suas afinidades com a direita no espectro ideológico e, por fim, a idéia de que a filiação religiosa tende a se traduzir em lealdades religiosas quase que automáticas ("irmão vota em irmão").

Conforme aponta a literatura, os fiéis evangélicos - sobretudo os membros das denominações pentecostais -, provêm de setores socioeconômicos significativamente desprivilegiados, tanto no que se refere à renda quanto ao nível de escolaridade. Esse perfil, no entanto, não é exclusivo ao segmento evangélico; ao contrário, guarda consideráveis similaridades com o público adepto das religiões católica e afro-brasileiras (candomblé e umbanda). Diante dessa semelhança de perfis, dificilmente eventuais diferenças de opinião, atitude ou comportamento entre esses três grupos podem ser atribuídas aos fatores acima mencionados - renda e escolaridade.

Mostramos como posições tradicionalistas dos evangélicos em relação ao aborto e ao homossexualismo não são necessariamente acompanhadas por posturas políticas conservadoras (o exemplo que utilizamos foi o posicionamento em relação à proibição de greves contra o governo). Essa dissociação torna difícil caracterizar os evangélicos como membros da base do que vem sendo identificado como "nova direita". As opiniões desse grupo diante de temas econômicos, além disso, acentuaram ainda mais a dificuldade de posicioná-los claramente à direita ou à esquerda do espectro ideológico.

Em relação ao comportamento eleitoral, vimos que parte significativa do segmento evangélico - com exceção dos fiéis da Congregação Cristã no Brasil optou pela candidatura de Anthony Garotinho no primeiro turno da eleição presidencial de 2002. Embora essa constatação em si só seja insuficiente para validar a tese de que a filiação religiosa evangélica tende fortemente a gerar lealdades políticas similares, a análise dos determinantes da escolha eleitoral e partidária revelou que a influência da igreja e das autoridades religiosas é desproporcionalmente maior no caso dos eleitores evangélicos.

O aspecto mais interessante da análise foi a dupla constatação de que, tal como os católicos, os evangélicos são pouco expostos aos meios de comunicação de massa, ao mesmo tempo em que (diferentemente de qualquer grupo religioso) têm um grau bastante elevado de exposição às autoridades religiosas de seus respectivos cultos. Como mencionamos anteriormente, essa carência de exposição às fontes de informação midiáticas transforma o público evangélico num segmento altamente passível de mobilização por parte dos líderes evangélicos - caso seja essa a decisão da hierarquia religiosa. Isso significa que os eleitores evangélicos, se 
mobilizados, podem a vir se interessar mais pelo universo político-eleitoral ${ }^{46}$. Também significa que, caso as muitas denominações consigam superar suas divergências e se unificar em torno de uma plataforma política comum, os evangélicos podem eventualmente se transformar numa clientela cativa de determinadas ofertas políticas.

\section{Bibliografia}

ALMEIDA, R. \& MONTERO, P. Trânsito religioso no Brasil. SP em perspectiva, 15 (3), p. 92-101, Julho-Setembro, 2001.

ALVES, Maria Teresa Gonzaga. Conteúdos ideológicos da nova direita no município de São Paulo: análise de surveys. Opinião Pública, VI (2), p. 191-229, 2000.

BURDICK, J. Looking for God in Brazil. The progressive Catholic Church in Brazil's religious arena. Berkeley: University of California Press, 1993.

FERNANDES, R. et al. Novo nascimento: os evangélicos em casa, na igreja e na política. Rio de Janeiro: Mauad, 1998.

FONSECA, A. Secularização, pluralismo religioso e democracia no Brasil: um estudo sobre a participação dos principais atores evangélicos na política. São Paulo. 262 páginas. Tese (doutorado), Universidade de São Paulo, 2002.

FRESTON, P. Evangelicals and politics in Asia, Africa and Latin America. Cambridge \& New York: Cambridge University Press, 2001.

FRESTON, P. Evangélicos na política brasileira: história ambígua e desafio ético. Curitiba: Encontrão Editora, 1994.

FRESTON, P. Protestantes e politica no Brasil: da constituinte ao impeachment. Campinas. 307 páginas. Tese (doutorado), Universidade Estadual e Campinas, 1993.

\footnotetext{
46 Perguntados se votariam caso não houvesse a obrigatoriedade da participação eleitoral, os evangélicos, ao lado das pessoas sem vínculos religiosos, em sua maioria, responderam que não votariam - evangélicos (54.3\%) e irreligiosos (57.2\%). Nos demais grupos, em contraste, formou-se uma maioria disposta a votar mesmo diante da não-obrigatoriedade do voto: membros do kardecismo
} 
GOMES, W. Nem anjos nem demônios. In: ANTONIAZZI, A. et al Nem anjos nem demônios: interpretações sociológicas do pentecostalismo. Petrópolis: Vozes, 1996.

KNUTSEN, O. Religious denomination and party choice in Western Europe: a comparative longitudinal study from eight countries (1970-1997). International Political Science Review, 25 (1), p. 97-128, 2004.

IBGE. Censo Demográfico 2000, Brasília: IBGE, 2000.

IBGE. Anuário Estatístico do Brasil 1982. Rio de Janeiro: IBGE, 1982.

LIPSET, S. M. O homem político. Rio de Janeiro: Zahar, 1967.

LÖWY, M. The war of gods. Religion and politics in Latin América. London, New York: Verso, 1996.

MANNHEIM, K. Ideologia e utopia. Rio de Janeiro: Zahar, 1972.

MONTERO, P. Religiões e dilemas da sociedade brasileira. In: MICELI, S. (org.). O que ler na ciência social brasileira. São Paulo: Sumaré \& ANPOCS, Brasília: CAPES, 1999.

MONTERO, P. \& ALMEIDA, R. O campo religioso brasileiro no limiar do século: problemas e perspectivas. In: RATTNER, H. (org.). Brasil no limiar do século XXI. Alternativas para a construção de uma sociedade sustentável. São Paulo: EDUSP \& FAPESP, 2000.

NOVAES, R. A divina política: notas sobre as relações delicadas entre religião e política. Revista da USP. São Paulo, 49, p. 60-81, Março-Maio, 2001.

Marco Zero, 1985.

Os escolhidos de Deus. Trabalhadores, pentecostais e cidadania. Rio de Janeiro:

ORO, A. P. A política da Igreja Universal e seus reflexos nos campos religioso e político brasileiros. Revista Brasileira de Ciências Sociais, 18 (53), p. 53-69, 2003.

PIERUCCI, A. F. O. Representantes de Deus em Brasília: a bancada evangélica na constituinte. Ciências Sociais Hoje. São Paulo, 11, p. 104-32, 1989.

PIERUCCI, A. F. O. \& MARIANO, R. O envolvimento dos pentecostais na eleição de Collor. Novos Estudos Cebrap, 34, p. 92-106, Novembro, 1992.

(63.9\%), adeptos das religiões afro-brasileiras (63.6\%) e católicos (52.7\%). O teste de chi-quadrado apresentou nível de 0.002, valor de 16.5478 (V de Cramér foi de 0.0839). 
PIERUCCI, A. F. O.; PRANDI, J. R. Religiões e voto: a eleição presidencial de 1994. Opinião Pública, 3 (1), p. 20-43, Junho, 1995.

PRANDI, R. Religião paga, conversão e serviço. Novos Estudos. São Paulo, 45, p. 65-77, 1996.

TOCQUEVILLE, A. A democracia na América. São Paulo: EDUSP, Belo Horizonte: Itatiaia, 1977. 